\title{
The origins of the emancipation campaign, November 1954 to May 1958
}

The military coup of 13 May $1958^{1}$ was marked by demonstrations of 'fraternisation' when Muslim women unveiled en masse on the Algiers Forum. This has been widely seen as a quasi-revolutionary moment that dramatically initiated the emancipation campaign. However, as will be seen in chapter 3, the illusion of a revolutionary break in May 1958 was successfully created by the propagandists of the psychological warfare bureau. Emancipation, far from springing forth perfectly formed as a triumphant expression of the popular will, represented the moment that a slowly maturing, but largely unseen, movement that had been gathering force over the previous two years suddenly came into the limelight. This process has gone largely unnoticed by historians in part because the government and army moved initially towards an agenda on Muslim women through a series of piecemeal initiatives and tentative experiments that were wrapped in considerable secrecy so that the FLN might be caught unawares, but also to conceal from French and international opinion the underlying military and intelligence logic of measures that it wished to dress in the clothing of liberal and democratic reform. However, an examination of this early stage is of interest, since the timing, and how and why the various initiatives were first undertaken, is informative as to the underlying concerns and objectives of the colonial authorities in moving towards such a strategy.

This chapter, which covers the first half of the Algerian War from 1 November 1954 until the coup of ' 13 May' 1958, falls into two parts. During a first phase from 1954 until mid-1956, which was dominated by the governorship of Jacques Soustelle, the Algiers government made little attempt to formulate a policy that was directly or explicitly aimed at Muslim women. The main initiative of Soustelle, who surrounded himself with fellow ethnologist advisers, was a classic 'Third World' developmental policy that aimed to improve the economic position of Algerian society as a whole, of which women just happened to constitute one category. However, from this reformist agenda emerged a number 
of new organisations, in particular the Section administrative spécialisée (SAS) and Centres sociaux, that were later to play a significant role in an overall strategy that targeted women.

The second and most important phase, which lasted from the summer of 1956 until the spring of 1958, saw the appearance of an intense debate that was focused for the first time specifically on Algerian women. It is difficult to determine whether the FLN or the French army was the first to deploy a 'liberation' strategy for Muslim women that the opposing side then responded to by adopting forms of counteremancipation. However, two events during July-August 1956 made a big impact on French opinion and created a general climate in which the issue of Muslim women moved onto the agenda. In July the European public was astonished to see in the press photographs of three young nurses in military uniform who had been captured by the army in the maquis, images that shattered the Orientalist stereotype of secluded and powerless Muslim women. ${ }^{2}$ A few weeks later, on 13 and 19 August, the newly independent states of Tunisia and Morocco announced major reforms of the marriage and family law. Suddenly the nationalists of the Maghreb seemed to be adopting a progressive position on Muslim women that threatened to harness their energy through modernisation, and to isolate France in international opinion as a reactionary colonial power. The Algiers government of Robert Lacoste responded over the next year, from behind the scenes, with a range of initiatives that included a propaganda campaign on emancipation and un-veiling, a working party on the reform of the marriage law, a debate on the extension of the vote to Muslim women, and a secret pilot operation to create and test new women's organisations. ${ }^{3}$ However, throughout 1957 we find evidence of growing tensions within the civil-military apparatus over a reform programme aimed at women: on the one hand Lacoste and an older generation of leaders were concerned that emancipation might trigger a strong religious backlash among conservative Algerians that would play into the hands of the FLN. Lacoste placed both the issue of the women's franchise and the project to reform the marriage code on the back-burner. On the other hand, late 1956 and early 1957 saw the surge to power within the army of a radical new force, the young colonels who detested the sclerosis of the Fourth Republic and supported the ideology of revolutionary warfare. This radical current was far more prepared to engage in unconventional forms of warfare and to develop a highly proactive 'liberation' of Muslim women that aimed to induce a profound psychological shock both in the French establishment and the FLN. While the colonels secretly tested out such new methods during 1957 in Operation Pilot, by May 1958 they were prepared to grab power 
in Algiers and to seize the opportunity to expand the experimental phase into a full-scale and open campaign of emancipation.

\section{Phase 1: November 1954-February 1956. Jacques Soustelle and the political development agenda}

As the Cold War rapidly deepened after 1945 US and NATO foreign policy centred on an over-riding fear that international communism was seeking to destroy the west via support for Third World insurrection, preying on the poverty and hunger of innocent peoples that were the victim of colonialism and under-development. The US government turned increasingly to academic specialists in the social sciences, including anthropologists, economists and social psychologists, to study the threat and through the 1950s and 1960s they produced an influential model of intervention often referred to as Political Development Theory (PDT). ${ }^{4}$ The model regarded Third World countries as highly vulnerable to insurgency, according to the adage 'poverty breeds discontent', and the role of the US and 'west' should be to provide a degree of economic aid and support so as to nurse fragile regimes through the transition to modernisation until they could stand on their own feet and establish democracy, political stability and nationhood. The PDT paradigm was one of state-building and the creation of efficient bureaucracies that could provide the necessary planning and administration to ensure economic well-being and security. Where Third World governments were coming under attack from communist-inspired insurgents they should, if necessary, be assisted by military programmes to contain this and to give them time to make the transition to modernity. Some analysts viewed modern armies as models of progressive, bureaucratic institutions, which could through direct military intervention or coups provide the most effective route to development and security: a model that had obvious implications for the French army control of a joint militarycivilian government in Algeria after January 1957.

While French policy documents on development reform and counterinsurgency during the Algerian War make very few explicit references to American theory, French practice overall moved towards an identical model. The Paris government, like the USA, utilised a large pool of academic social scientists to investigate and recommend policies in relation to the 'Algerian problem', and without doubt these specialists were aware of US thinking and helped to transmit such concepts into the army and civil service. ${ }^{5}$ The Governor, Jacques Soustelle, as a leading ethnologist was well placed to pick up on contemporary PDT and he, in turn, had recourse to the appointment of experts like Germaine Tillion and 
Vincent Monteil. But France had its own long-established institutions of state-planning led by the technocrats of the grandes écoles and it should come as no surprise that they should develop Algerian policy documents in a peculiarly French style which, while they carried few references to US doctrine, arrived at similar conclusions on the developmental answer to insurgency. ${ }^{6}$ In December 1954 ex-Governor Naegelen claimed that the loss of North Africa would, in a domino effect, lead to the loss of the whole empire, 'It would push France down to the level of a secondary power and even to vassal status', and for General Calliès, 'North Africa has become the No 1 stake in the Cold War'. ${ }^{7}$ The immediate response to the insurrection was to design a dual strategy, one of repression and social and economic development.

Less than three months after the outbreak of the Algerian War, on 25 January 1955, Soustelle, a leading Gaullist, was invited by the socialist Prime Minister Mendès-France, and the Minister of the Interior, Mitterrand, to take on the key post of Governor General. The Mendès-France government had taken a progressive stance on the issue of de-colonisation and moved rapidly to end the catastrophic war in Indo-China (armistice of 21 July 1954) and to disengage from Tunisia (Carthage Declaration 31 July 1954). Although the government was brought down in February by a powerful right-wing colonial lobby that feared Morocco and Algeria were also about to be 'abandoned', Soustelle's appointment remained in force and on his arrival in Algiers the European settlers regarded him with deep suspicion and hostility. However, within a year the Governor had become a hard-line supporter of Algérie française and had become the hero of pieds noirs ultras who mobbed him on his departure from the Algiers docks on 2 February 1956. ${ }^{9}$

From the moment of his arrival in February through to April 1955 the new Governor studied at first hand the conditions in rural Algeria and was particularly struck during an early tour of the epicentre of rebellion in the Aurès mountains by the profound poverty of the people. $\mathrm{He}$ quickly elaborated the 'Soustelle Plan' for the accelerated development of the colony. ${ }^{10}$ The crisis and endemic poverty confronting Algeria was not, he argued, the consequence of an exploitative colonial system and France had since 1830 brought enormous benefits to a primitive society wracked by tribal wars, disease and famine. Algeria did face major problems of poverty and unemployment but these were not caused by colonialism but rather reflected a classic problem of 'under-development' rooted in such inherent problems as infertile soils, lack of rainfall, a population explosion and other 'natural' or technical aspects. Since, claimed Soustelle, France invested more in Algeria than it received, 
and future industrialisation and modernisation could only be achieved through French assistance, it was of crucial interest to all Algerians that they remain part of France. For the Governor the way to defeat the FLN rebels, whom he characterised as a small and unrepresentative minority of 'fanatics' supported by external pan-Arab, and particularly Nasserite, interests, was to isolate them from the mass of the Algerian people. The tap-root of rebellion could be cut through economic and social development that would remove the causes of discontent by an increased investment in agricultural reform, irrigation, transport infrastructures, education, health care, training programmes and combating unemployment.

Soustelle appears to have shown little interest in elaborating policies that targeted Algerian women in particular, apart from passing references to their backward condition, 'Often women do not know how to care for a child or to sew'. ${ }^{11} \mathrm{He}$, like his advisers at this time, prepared more global economic and social development programmes that through improvement of agriculture, housing, health and education would implicitly improve the lives of women, but there was no conscious effort to address specific women's issues or to formulate a policy. In general Soustelle viewed Algerian society as so tied to conservative tradition that there was little point in confronting the issue of emancipation. On his appointment as Governor Soustelle inherited from Mendès-France a brief 'Reform Plan under consideration by the former government', which recommended the integral implementation of the 1947 Statute, including extension of the vote to Muslim women (see chapter 1). ${ }^{12}$ Significantly in this instance Soustelle followed the position of his predecessor Léonard, using the excuse of Muslim conservative opposition to block any initiative. It would have been easy, claimed Soustelle, to organise, 'during a first phase a project in favour of women who were sufficiently advanced (évoluées). But the enthusiasm shown by Muslims in this respect has been so lukewarm, to put it mildly, that I think it would be a mistake to move too far ahead of their beliefs'. ${ }^{13}$ Soustelle was irritated by the opposition he faced to his plans from Alice Sportisse, champion of the female franchise in the Algerian Assembly, and he regarded the UFA as a communist front organisation, which he finally banned with the PCA on 12 September $1955 .^{14}$

However, while Soustelle seems to have shown little interest in the question of Muslim women, he did make other innovations which from late 1956 onwards were to play a big part in the future evolution of an emancipation agenda: the creation of the SAS and the application of ethnographic field practices to the study of Algerian society, particularly through the creation of the Centres sociaux. On his appointment 
as Governor Soustelle travelled almost immediately into the Aurès mountains, long the preferred location for anthropological fieldwork in Algeria, where he noticed the almost total absence of any French administrative structure and personnel, so that the Muslim population was abandoned to desperate poverty, and 'we have allowed a huge void to be dug'. The way of life of such rural people remained profoundly archaic and any attempt to rebuild contact needed to be 'on the solid base of a scientific knowledge of their social structures and their system of values' ${ }^{15}$ There was a long tradition within the French colonial service, as of so many other European imperial regimes, of 'ethnopolitique', ${ }^{16}$ utilising the most advanced academic sociological, anthropological and linguistic knowledge to decode 'primitive' societies, the better to control them: indeed, colonial regimes were themselves highly productive of such specialised knowledge through the work of administrators and military officers who spend many years 'up country' in close contact with native customs. ${ }^{17}$

Soustelle's professional background as an ethnologist meant that he was well-equipped to effect such a juncture: Soustelle, and his Tunisian-born wife Georgette, had worked together as ethnographers in Mexico and Guatamala between 1932 and 1934 and 1939 and 1942, and achieved international acclaim as authorities on pre-Colombian Mexican civilisation. Soustelle was much influenced by Mexican rural development projects, the 'cultural missions', which provided an integrated approach to adult education by linking it to basic issues of health, literacy, welfare and housing. ${ }^{18}$ This connected approach to issues of poverty was stated in a key definition of June 1955: 'The foundation education addresses itself to all those men, women and children who could not benefit from conventional schooling. It aims to mount a co-ordinated attack on all the causes of poverty by actively involving the subjects themselves in the struggle'. ${ }^{19}$

This developmental approach can be seen at work in Soustelle's creation of the SAS in September 1955, which was to prove to be one of the most innovative organisations in military 'pacification'. This was based mainly on the experience of the old Algerian Bureaux arabes and the Moroccan Affaires indigènes, by which enterprising officers were permanently located among the isolated and impoverished peasantry of the bled where they engaged in a huge range of tasks: building schools, roads and irrigation projects, tackling unemployment through jobcreation projects, improving agricultural production, providing medical assistance, regulating local disputes, and all the other tasks that local government should in principle have provided. ${ }^{20}$ Although the SAS, at least during the first year of operation, had no explicit instructions or 
remit to address the problems faced by women, inevitably contact with the harsh reality of the conditions faced by local populations quickly raised pragmatic issues of how to gain the co-operation of illiterate women in relation to child-care, school attendance, water supply, health and other matters. The army command quickly came to see the SAS as a key instrument in its overall emancipation programme at local level.

Soustelle recruited two outstanding sociologists, Vincent Monteil and Germain Tillion, and attached them to his cabinet as advisers. Monteil (1913-2005), whom the orientalist scholar Louis Massignon regarded as his spiritual heir, ${ }^{21}$ was one of France's leading experts on Islam which he studied closely during an adventurous army and academic career that took him first to Morocco (1938-48) as an officer in the Affaires indigènes, and then as a high-level military attaché to Tunisia, Palestine, Iran, Indo-China, Algeria and French West Africa. ${ }^{22}$ A close friend of Mendès-France, whom he had known as a prisoner in Riom during the Second World War, Monteil, who had a deep empathy for Muslim society and later converted to Islam, favoured a federal and an early negotiated settlement of the Algerian crisis. When Soustelle first flew as Governor to Algeria he was accompanied by Monteil as head of his military cabinet with the task of making 'contact' with Muslim society. Monteil became rapidly disillusioned with Soustelle's marked shift towards the right, his tolerance of torture, and growing support for a guerre à outrance against the nationalists, and resigned his post on 24 June $1955 .^{23}$

Although Monteil was attached to the General Government for only six months, it seems likely that during this period he was responsible for introducing into the army and administration his expert comparative knowledge of Soviet policy in Muslim Central Asia. Monteil had studied, among other sources, the reports of an Algerian delegation to Uzbekistan in 1950, which was headed by General Tubert, and included the writer Kateb Yacine. ${ }^{24}$ This was informed by its Soviet hosts of the advances made in the emancipation of Muslim women, particularly through the great campaign against veiling of 1926-27 and the Constitution of 1936 that made it illegal to engage in acts of resistance to female liberation including marriage of minors, polygamy, refusal to educate girls, or opposition to their full voting and political rights. ${ }^{25}$ The problems that the Soviet Union faced in the inter-war period as a secular colonial power trying to impose its political authority on a deeply resistant Muslim and traditional tribal society provide close historical parallel to the situation faced by France in post-war Algeria. ${ }^{26}$ Monteil was fascinated by the lessons that could be learned from the earlier Soviet experience, and was aware that in Algeria, as in Central Asia, no global 
social, economic and political progress could be made without a radical emancipation of women. However by the 1950s, after forty years of Soviet endeavour, many traditional practices, including veiling, seclusion, pre-pubescent marriage and polygamy remained entrenched, even among members of the Communist Party. Monteil attributed this failure to an external political emancipation imposed on Asian society that had not undergone a real, internal transformation of values, and held up the best and most optimistic sign for progress in the Maghreb in the enormous aspiration of Muslim women for education. ${ }^{27}$ Although Monteil left the cabinet in June 1955, his understanding of the Soviet experience would have reinforced Soustelle's belief that the situation of Algerian woman could only be transformed by long-term reform, and that any replication of a Soviet style radical confrontation with Muslim society was doomed to failure: a position that Soustelle seemed to abandon three years later during the events of '13 May' 1958 (see chapter 3).

The second key member of Soustelle's small team of expert advisers was the ethnologist Germaine Tillion. From 1934 to 1940 Tillion had, along with Thérèse Rivière, carried out fieldwork in the isolated mountains of the Aurès region, an experience that had provided her with intimate knowledge of the language, culture and traditions of women in the Chaouia tribes. ${ }^{28}$ The main centre of the rebellion of 1 November 1954 was in the Aurès mountains and Louis Massignon, deeply disturbed by the fear that the French air-force would bomb the hill tribes with napalm, was able to arrange a meeting with Mitterrand, the Minister of the Interior, to which he invited Tillion. ${ }^{29}$ Tillion, as an expert on the Aurès, was given a three-month mission to study and report on the conditions underlying the revolt.

On her return via Algiers Tillion reported her findings to Soustelle, whom she had known twenty years earlier in the Musée de l'Homme, the pioneer centre of French inter-war ethnography. The Governor invited Tillion to join his cabinet team as a chargé de mission, where she worked closely alongside Monteil on a study of the economic and social problems faced by Algeria. Despite the fact that Tillion, who had lived for years sharing the daily lives of Chaouia women, had a closer knowledge of rural women than almost any other European, and several years later was to write one of the most influential studies of Muslim women, Le Harem et les cousins (1966), ${ }^{30}$ she does not appear to have developed specific proposals in relation to them during 1955-56. This is in part because Tillion's remit was to study the enormously complex and global problems facing colonial Algeria as a whole, as can be seen in a study which she wrote in late 1956, misleadingly published as L'Algérie en $1957 .{ }^{31}$ 
However, this study does contain a powerful, but implicit, policy in relation to Algerian women. When Tillion arrived in the Aurès region in December 1954 after a fourteen-year absence she was profoundly shocked by the massive economic dislocation and 'pauperisation' of the previously stable 'archaic' society. ${ }^{32}$ For Tillion the root causes of this deepening poverty did not lie with colonialism, 'that hoary scapegoat', which she characterised as a nineteenth-century phenomenon, but rather with a classic Malthusian crisis in which a galloping growth in population would massively outstrip natural resources. France was not viewed by her as in an exploitative or damaging colonial relationship with Algeria: on the contrary the best, and perhaps only, chance for Muslim people to avoid catastrophic Third World poverty was through an ongoing French presence and assistance in the form of investment by Paris, the skills of the European minority, the income generated by labour migration to the metropolis, industrialisation and mass education. A nationalist victory would spell total disaster: an independent Algeria would be unable to 'go it alone', incapable even of developing the enormous potential of the newly discovered Saharan oil fields. Tillion's analysis was not particularly original and reflects the conventional post-war analysis of French demographers and technocrats like Louis Chevalier who also elaborated a Malthusian agenda that remained blind to the destructive impacts of colonial domination. ${ }^{33}$ Tillion's reformist position up to 1957 , which can be characterised as an 'ethnographic liberalism' or a diffuse Christian socialism, ${ }^{34}$ like that of Monteil, Camus and other humanists, suffered from the illusion that a reformed colonialism could even at this late hour endure within the paradigm of a French-Algeria. ${ }^{35}$

Tillion's answer to the 'woman question' in Algeria, in line with her developmental model, did not address the issue of a political solution, or relate Muslim women to the question of nationalism or independence, but rather provided the answers through an economic and modernising agenda. Algerian women were viewed in global terms, in relation to a Malthusian model, as rapid breeders of babies. The solution to the inevitable process of pauperisation was not birth control, a practice that was seen as a 'cruel joke' within the logic of an 'archaic agricultural civilisation', ${ }^{36}$ but rather universal education. Tillion estimated that some 98 per cent of all Muslim women were illiterate, while only one in sixteen girls was receiving primary education. But this did not mean that women were sunk in ignorance as to the possibilities of a better life: 'In the towns, they now go to the cinema, they listen to the radio, either at home or a neighbour's, they gossip among themselves, they get to know things, and even in villages out in the back of beyond I heard remarks of 
an astonishing bitterness last year', a bitterness that related to repudiation, lack of rights over children, and other features of Islamic law and custom. ${ }^{37}$ Tillion had optimistically recognised here a popular thirst and potential for education as the key to modernity, and this perception led her to establish the Centres sociaux.

The Centres sociaux, created by the decree of 27 October 1955, although financed by the Ministry of National Education, were not part of the conventional school system, but training programmes designed for illiterate adults and youths who had received little if any state education: teams of teachers, social and health workers that according to Soustelle would work, 'without dogmatism or inflexibility, combining basic instruction, post-school education, hygiene, and simple trade skills' ${ }^{38}$ Although Soustelle and Tillion have been widely credited with the invention of the Centres sociaux, the prototype for such training centres had existed from about 1951 in the deprived shantytowns of Algiers. In 1953 Father Scotto, in collaboration with professionally trained social workers, Marie-Renée Chéné, Emma Serra and Simone Galice, established, with the support of the municipality of HusseinDey, a social centre in the shantytowns of Bel Air. ${ }^{39}$ Chéné had arrived in Algeria as a militant of the Service civil international (SCI), an NGO that specialised globally in social work in impoverished urban slums. ${ }^{40}$ The deepening crisis in traditional rural society had, since the 1930s, driven huge numbers of impoverished peasants from the interior into the mushrooming shantytowns of Algiers and other major cities, a flight from the land that accelerated further after 1955 as the army, through its 'free-fire' zones, created a serious refugee problem (see chapter 6). ${ }^{41}$

The shantytown of Bel Air, in which the Scotto team operated, provided a typical example of a general urban crisis: 6,500 people lived there in appalling unhealthy conditions, with no piped water, sewerage system or surfaced roads, and the nearest medical dispensary was ten kilometres away. By 1962 the rural exodus had inflated the population to $35,000 .^{42}$ The social workers established a small dispensary in the bidonvilles, delivered water by tanker, and set up courses to help Muslim women with literacy, domestic skills and health care. In early 1955 Germaine Tillion, accompanied by another ethnologist, Georgette Soustelle, ${ }^{43}$ visited the centre at Hussein-Dey, while Father Scotto was invited to a meeting with the Governor, Tillion and Monteil, to discuss his work. ${ }^{44}$ The Bel Air centre thus served as a practical model and Tillion invited Emma Serra to help set up the new Centres sociaux, which grew in number from eleven in late 1957, to 125 at independence. Nelly Forget, who worked in the Centres sociaux, notes that they marked a significant breakthrough by attracting large numbers of young 
women, who until then had been confined to low-skill, exploitative labour as domestics, and trained them as health and domestic skill monitors. This, combined with a mixed-gender work environment, began to create a new, positive image for Algerian women: ${ }^{45}$ but one, as will be seen below, which attracted the unwanted attention of both European ultras and of the army intelligence services.

\section{Phase 2: March 1956 to May 1958. Lacoste and radicalisation of the emancipation agenda}

Soustelle, after his departure on 2 February 1956, was replaced by Robert Lacoste, after the new Prime Minister Guy Mollet was forced into a humiliating withdrawal by violent Algiers demonstrators to abandon General Catroux, his first choice as Governor. This February crisis marked a major watershed in the war, the abandonment of a possible early negotiated settlement with the nationalists for a deepening military repression that locked France into one of the longest and bloodiest wars of decolonisation. ${ }^{46}$ On 16 March 1956 parliament passed a Special Powers Act that enabled Paris and the minister in Algiers ${ }^{47}$ exceptional authority to introduce measures to combat the FLN, including the surrender of both civilian and military authority to the generals. At the same time Mollet announced the extension of conscription and the massive increase of the army presence in Algeria to 450,000 men, an expansion that marked an overall militarisation of Algerian government and civil society. The rapid increase in the power of the generals, which was capped by the appointment of General Salan as overall commander in December 1956, led to a radicalisation in the doctrine and practice of colonial warfare.

Robert Lacoste, as ministre résident between 9 March 1956 and 10 May 1958, has generally been seen by historians as responsible for overseeing a phase of unprecedented military violence and repression, including the widespread use of torture. Daniel Lefeuvre has criticised this accepted opinion by noting Lacoste's involvement in a major programme of economic and social reform to tackle, 'the problems posed by the poverty of the majority of the population' ${ }^{48}$ But the simultaneous pursuit of both repression and reform, far from being incompatible, was a key feature of French military strategy, and Lacoste's simultaneous acceleration of both aspects deepened the central, and ultimately fatal, contradiction of the war as a whole. At the centre of this dual agenda lay the emergence, particularly from August 1956 onwards, of a new policy that was specifically aimed at the 'conquest' via emancipation of Algerian women. 
One indication of a change of direction appeared on 5 February 1957 in the form of an influential and provocative article by the journalist Monique Difrane in Le Figaro, under the title 'Liberation for Algeria? Yes! That of Women' ${ }^{49}$ The French right-wing press served, throughout the war, as the unofficial voice of the army, and journalists, as was undoubtedly the case here, frequently served to transmit propaganda on behalf of the armed forces. It is significant that Difrane's article appeared at this particular moment in time, and the argument and style of the piece provides interesting evidence of a propaganda discourse that undoubtedly reflected the new thinking of the army but which it did not, as yet, wish to publicise.

Difrane claimed to have just returned from a journey to the interior of Algeria, a trip that would only have been possible under the protection of the military, where she had visited and conversed with Kabyle and Arab women of all ages and classes who had raged in despair against their oppression by Muslim patriarchy. The author reassured her conservative readership that her agenda was not 'a more or less futile story of "suffragettes" lending itself to laughter and mockery', but a question of representing the authentic and insistent voice of Algerian women who were demanding change. The Muslim woman, 'is a prisoner for life, confined, isolated, cooped up between the four walls of her house or hut', a baby-making machine subject to 'annual pregnancies', who could at any moment be repudiated and expelled penniless into the street. Difrane's emphatic claim to convey the authentic voice of all Algerian women, their precise words and experience, needs to be treated with caution and her text appears to reproduce the discourse of the minority of educated évoluées (see chapter 1) rather than the opinions of the great mass of illiterate peasant women.

Difrane presented an argument that fell into two parts. Firstly, she analysed the various social forces at work within the colony that conspired to maintain women in such a state of servitude, in particular the Algerian 'taboo', the fearful conspiracy of silence surrounding the issue. Even those husbands of Muslim women who would like to change things by, for example, going out in public as a couple, were afraid to break with tradition because of the reprobation of Algerian society and 'what the neighbours may say'. The status quo was also reinforced by the religious leaders and imams, the Ulema heads like Tawfik al-Madani, who defended the sacred right of Islamic law and custom not to be interfered with by secular government. One highly educated woman, described as 'very évoluée', had buried her head in her hands, saying: 'If anybody congratulates themselves before me on this respect for our religion, our customs, our personal status, I think: "He's an enemy!". Since he drives 
us into a different world from his own, and slams shut the ancestral status on us like an iron gate!'.

But, claimed Difrane, the taboo was also sustained by European society: the main culprits here were the French women, the wives of army officers and other 'ladies of good deeds', whose benevolent work with Algerians was limited to charitable hand-outs, 'baby clothes for the fifteenth child ... the cooking of fritters, embroidery' and who 'preach to Muslim women resignation to an unbelievable fate, as if the latter was without a mind or heart'. The European woman regarded the Muslim woman as so inferior, so abject and 'absolutely vacuous' that she was thought incapable of expressing any opinion, and was treated as a passive object rather than as a human being. European charitable workers had thus failed to pick up on the volcanic pressures building up among Muslim women for radical change, and also served to block reform through a dangerous 'respect for customs'. Difrane was reflecting here the idea of a 'double imperialism' that had been expressed by young Muslim nationalists and évoluées of the JUDMA during 1951-54 (chapter 1) according to which women were crushed under the double weight of conservative Muslim and European colonial forces. Soustelle had also expressed this idea: while European ultras persisted in refusing Muslims full citizenship 'on the pretext that the latter would be incompatible with their Islamic "personal status", on the Muslim side the extremists push their fellow believers to reject this same citizenship as incompatible with their salvation' ${ }^{50}$

Secondly, Difrane argued that, breaking through the 'taboo' on women's condition, she was able to uncover among frustrated Muslim women an enormous pressure for change: 'For long these cloistered and crushed beings have remained silent, rendered stupid by their suffering, but the undeniable fact of the present is the awakening of their consciousness'. France, one Muslim told her, had abolished slavery, but not for women and she then appealed for measures that, probably not a coincidence, were identical to the legal reforms secretly being explored by the Lacoste government at that moment: 'Give us marriages in the town-hall, give us new laws, suppress the Muslim magistrates (cadis), suppress the ease with which husbands use repudiation, arrange things so that we can hang the veil in the window since it's only useful as a curtain!' Difrane argued that the key plank of government policy, to retain the colony through integrating the French and Muslim communities and by reform of the electoral system could not work until a revolution like that of Atatürk had been achieved. 'One cannot dissolve two societies into one when one reflects the Middle Age and the other the Twentieth Century'. This was no time for half measures: what was 
needed was education and modernisation for women and tackling the most urgent problem facing Algerian society, the demographic explosion. The stakes were high and, since four million Algerian women were looking to France, this was an opportunity to be seized: 'Behind the blind walls seethes an inevitable revolution which will be made against us if it is not made with us and by us'. Difrane was giving voice here to an emerging current of thought among the radical advocates of psychological warfare: victory would be dependent on the emancipation of Algerian women and France must move urgently to appropriate this agenda before the FLN. Behind the scenes this U-turn in colonial government and armed forces thinking on Muslim women was dramatically precipitated by the rapid move of Tunisia and Morocco towards radical reform of the marriage and family codes.

\section{The Tunisian challenge: reforming the personal status law}

One of the most important steps that Muslim nation-states were able to take during the twentieth century to emancipate women was to introduce a comprehensive and radical legal code on women, marriage and the family (statut personnel). ${ }^{51}$ On 13 August 1956 Tunisia introduced, only five months after independence, what has been widely regarded as one of the most progressive Codes ever passed by a Muslim country. ${ }^{52}$ Six days later, by the order of 19 August, the King of Morocco also established a commission for the reform of the code of personal status. ${ }^{53}$ The Tunisian Code established a minimum age for marriage (fifteen for women, eighteen for men); made the consent of both spouses mandatory, preventing the tradition of enforced marriage; required that marriage be a civil matter, with formal registration; banned male repudiation of wives, while requiring divorce to be also a civil matter, enacted in a court; banned polygamy; and set out clear rules in relation to dowry, property rights, inheritance and care of children after separation. Such legislation was not without precedent, and Tunisia was able to draw upon the experience of earlier reforms, including those of Kemal Atatürk in 1926 and the Syrian Code of 1953, as well as international resolutions like that of the Third Congress of the Union féministe arab, passed by representatives from Egypt, Lebanon, Syria, Jordan, Palestine and Iraq at Beirut in June 1954. ${ }^{54}$

This innovation was watched very closely from across the border by the Algiers government, and three months after the promulgation of the Bourguiba Code Robert Lacoste secretly consulted Prefects and the super-Prefect (IGAME) ${ }^{55}$ of Constantine on proposals to reform the personal status law. Lacoste noted that it was important to keep up 
with changes in society, and 'not to ignore the efforts of renewal and modernisation of Muslim law being pioneered for many years now by the Muslim countries of the Mediterranean basin'. ${ }^{56}$ Bourguiba, in two speeches of 3 and 10 August 1956 announcing the new Tunisian Code, noted that change was in the national interest, so that 'Tunisia does not remain an abomination among the civilised nations of the world', while social justice could not tolerate half of society being grossly marginalised. ${ }^{57}$ France was reacting to an embarrassing situation in which its Algerian colony might begin to appear highly retrograde on women's rights by comparison with its newly independent neighbours. Tunisia and Morocco, as soon as the authority of France was removed or weakened, were able to forge ahead and prove themselves to be more liberal on women's emancipation, so dangerously exposing French symbolic claims as the very founder and defender of revolutionary universal rights.

Further light was thrown on official thinking in a report drawn up for the government by Henry Le Breton, Emeritus professor of law at Algiers University. In a close legal critique of the Tunisian legislation, while arguing that the substance of the Code was not as radical as it might appear, he praised the suppression of polygamy and repudiation, which helped stabilise the family. The danger was that the Code threatened to stir up opposition among religious conservatives, but 'let's be thankful that it has been carried out in Tunisia by a Muslim government. We thus have, in the near future, the demonstration of what is possible in this field in Algeria'. The Bourguiba reform was an act of bravery for a Muslim government and, 'for the modernisers of the Neo-Destour Party, a resounding propaganda success which they have not been reluctant to use' ${ }^{58}$ Le Breton was pointing to the fact that the over-cautious Algerian government had for decades simply refused to consider any significant reform in the sphere of women's rights because of a real, or imagined, backlash by powerful religious interests. The Bourguiba Code had the merit of demonstrating that reform of personal status law was not necessarily an agenda imposed from without by a western and infidel regime, but was perfectly compatible with orthodox Islam. It opened the path to France doing likewise, and demonstrated that this was not only politically possible but also desirable.

In late April 1957 Lacoste sent an order to Champeix, Secretary of State for Algerian Affairs in the Ministry of the Interior, to prepare as a matter of urgency draft proposals (avant-projet) for a reform of the legal status of Muslim women. ${ }^{59}$ A working party met in four sessions in the Paris Ministry of the Interior during May-June 1957, and among its rather changing membership were experts in Muslim family law and 
senior members of the Algerian administration, including the chair, Eugène Simoneau, Directeur des affaires d'Algérie in the Ministry of the Interior, and Louis Milliot, former dean and professor of law in the University of Algiers. Milliot was given the task with Raymond Charles, Conseiller of the Paris Appeal Court, of drawing up the highly technical draft Code. ${ }^{60}$ The recommendations of the final report, ${ }^{61}$ which was shelved until late 1958, will be considered in a later discussion of the final statute introduced by the Gaullist government in 1959 (chapter 8), but here the concern is with what the working party reveals about the motivation of the government in undertaking an emancipation agenda in mid-1957.

The chairman repeatedly emphasised the great urgency of the project, and that this clearly arose from the need to respond to the enormous public interest generated by the Bourguiba Code and for France not to be perceived as more backward than Tunisia. The group had been instructed by government, noted the chairman, 'to go as far as possible in the direction of a real emancipation of the Muslim woman, and to go at least as far as the new Tunisian Code'. ${ }^{62}$ It is noticeable that the working party contained no Algerians, although it was intended that the proposals be later referred to some Muslim religious 'notables'. Nor were there any women members until the penultimate meeting agreed that Marie-Hélène Lefaucheux, president of the Union des femmes françaises et musulmanes d'Algérie, should be briefed and invited to the final session. ${ }^{63}$ As we have seen, Lefaucheux, as chair of the UN Commission on the Status of Women, had already placed pressure on the government for reform during 1951-53. After the UN General Assembly on 1 October 1955 voted to place the Algerian problem on the agenda, a shocked French government became intensely concerned to fend off international criticism of its colonial regime. ${ }^{64}$ After the UN adoption of the Convention on the Political Rights of Women (20 December 1952) the attention of the CSW turned to the global reform of discrimination in marriage (consent to marriage, minimum age, civil registration) as well as traditional or customary practices that were harmful to women, such as claustration and genital mutilation. ${ }^{65}$ This international UN agenda brought further pressure to bear on the French government, and Lefaucheux, with her intimate knowledge of the CSW, may have been brought on board to help formulate a reform that would counter the critics of French colonialism. ${ }^{66}$

Lacoste, in parallel with the establishment of the working party, sent instructions on 9 May 1957 to the Algerian Prefects and IGAME to seek their opinion on seven specific themes: the general desirability of reform, the act of marriage (consent, age, etc.), repudiation, polygamy, veiling, 
seclusion, inheritance and political rights. The replies provide an insight into official thinking on emancipation across the different regions of Algeria at an early stage in the debate. ${ }^{67}$

Most Prefects were in favour of ending repudiation and ensuring that divorce was legalised by a court decision, a measure that was seen to help stabilise the family unit. Likewise polygamy could be readily banned since it was in decline and survived only among a small number of rural traditionalists. But the general tone of the reports was one of caution and a reluctant acceptance that some change was needed to catch up with inevitable social change and to contain growing pressures for reform. Change, however, could not be too advanced since it was likely to stir up opposition of older men who, as the Prefect of Orléansville noted, feared 'an overturning of religious principles'. Such caution was particularly advisable in a situation of war: as the Prefect of Tlemcen remarked, reform was desired by young évoluées women, 'But in the present conjuncture of events such an initiative is inopportune and carries the danger of playing into the hands of the FLN'. The Prefect of Sétif expressed the opposite concern, 'We must avoid allowing ourselves to be overtaken in this field by the nationalists'.

The tension between those who argued against reform on the grounds that it would alienate an intensely religious society and reinforce support for the FLN, and those who defended the urgency of reform, or risk seeing the FLN seizing the initiative, was to plague the French government over the next three years. The majority of Prefects avoided this dilemma by favouring a gradualist and long-term preparation of Algerian society, particularly through the education of women. The Prefect of Bône, who opposed enfranchisement since, 'the FLN will give out orders that will be followed by women', thought reform would be best carried out by Muslims themselves 'in a pacified Algeria'. The IGAME of Constantine, Maurice Papon, agreed the time was not right for reform, and in line with his espousal of the techniques of psychological warfare, ${ }^{68}$ he placed more emphasis on propaganda (producing 'a psychological shock') based on prior scientific investigation of Algerian public opinion: 'Opinion polls and preparatory campaigns through the intermediary of the press and radio to study the reactions of the Muslim masses. The development of women's cultural, social, and political organisations as well as the increase in contacts with European women'.

It is difficult to piece together from the archives the line of thinking of Lacoste between mid-1957 and the collapse of the Fourth Republic in May 1958, but it seems likely that he was sufficiently worried by the political repercussions of a religious and nationalist backlash against 
legal reform, that he decided to shelve the draft Code submitted to him in June 1957, while holding the line with some minor, window-dressing measures. The law on labour relations of 6 August 1954 granted Muslim women the right to take part in elections to industrial tribunals (prud'hommes), a fairly limited right that was first exercised on 16 June 1956 and was regarded by the colonial government as a 'success' ${ }^{69}$ The law of 11 July 1957 (régime des tutelles) made one significant change to the complex mosaic of personal status or family law by enabling married women to retain care of their children on the death or long-term disappearance of their husbands, whereas previously, under Islamic law, children reverted to the guardianship of male relatives. ${ }^{70}$ Significantly, even this minor reform which was hedged about with conservative restrictions, met with strong resistance from Muslim justices and was viewed as a daring innovation by the Algiers government.

The main tactic of Lacoste was to put off both full enfranchisement as well as introduction of a complete code on women's status until implementation of a new local government act (loi cadre) passed on 5 February 1958. In several debates in the Senate and National Assembly on the law during November 1957 to January 1958 two centre-right deputies, Marcelle Devaud and Francine Lefébvre, failed to carry amendments to guarantee the extension of the vote to Algerian women. They argued that their exclusion was discriminatory and in breach of the French Constitution. Devaud noted that this exclusion was in contradiction with, 'the dramatic global emancipation of women ... Do we have to wait to be shown the way by Nasser in Egypt, Bourguiba in Tunisia, and Mohamed V? ${ }^{71}$ Francine Lefébvre in the National Assembly on 28 January 1958, attacked the blatant racial and sexual discrimination: 'as a woman, I am shocked to see that you care so little about the opinion of women. One really gives the impression of believing that Muslim women are absolutely incapable of forming an opinion or expressing themselves'. She also held up the dangers of revolt: 'If today we do not know how to respond to the hopes of these women they will begin to pay attention to the siren voices that sing from Cairo' ${ }^{72}$ It is noticeable that Devaud, Lefébvre and Lefaucheux, who were agitating for the rights of Algerian women between 1951 and 1958, shared a similar background, that of the generation of Resistants who, although members of conservative or centrist parties, came to play a major political role in the organisations of French feminism. ${ }^{73}$

In reply to Lefébvre's attack in the National Assembly Robert Lacoste, the Minister for Algeria, noted that the Organic Law of 20 September 1947 had insisted that Muslims be consulted on such a crucial issue as the vote and that this had been delegated to the Algerian Assembly (see 
chapter 1). Now that the Assembly had itself been dissolved by decree (12 April 1956), this power should pass on to future regional assemblies, proposed by the loi cadre, in which Algerians would be represented. At the same time Lacoste insisted on the need to be cautious and to avoid a backlash from Muslim society. ${ }^{74}$ Through this sleight of hand, Lacoste was following closely in the footsteps of his predecessors, Naegelen and Léonard: firstly, any major reform relating to women could be deferred and elected Muslim political leaders could be expected to block any such initiative. Secondly, even if significant changes were introduced this would be seen to be coming from Muslim representatives themselves and thus dampen any potential opposition and unrest to French interference in the religious sphere that might play into the hands of the FLN. This was in keeping with the advice of an official in the General Government, that no matter how hard Muslim feminists were pushing for 'revolutionary' change of their status, 'any initiative coming directly from us carries the risk of being falsely interpreted and giving rise to tendentious reactions' ${ }^{75}$ As in 1948, Lacoste, by deferring action to local assemblies, was able to delay reform safe in the knowledge that conservative Muslims could be relied upon to prevent any 'revolutionary' agenda and that any failure of reform could be blamed on 'backward' Algerians themselves.

The 1957-58 debate on the women's franchise and the personal status law reflected the more overt public and reformist side of Lacoste's dual approach. Investigation of these policy initiatives lay very much in the hands of civil servants or administrators, advised by lawyers and academic specialists in Muslim law, who tended to reflect the cautious and conservative traditions of the General Government in relation to any innovations that affected the religious sphere. However, in tandem with this, but working in a far more secretive way were the psychological warfare officers of the Fifth Bureau who were interested in the counter-insurgency and repressive implications of women's emancipation. This newly emerging force that was gathering strength within the army was far more prepared to engage in bold initiatives that might directly challenge the 'reserved area' of Muslim faith and practice.

\section{Rural counter-insurgency: Jean Servier and the emancipation programme, 1956-58}

The single, most distinctive feature of the French army in Algeria between 1954 and 1962 lay in the enormous political influence of the doctrine of 'revolutionary warfare' which permeated all levels of the armed forces and came to constitute a parallel structure within the military hierarchy 
and government. ${ }^{76}$ The theory was developed primarily by army officers, most notably Colonel Charles Lacheroy ${ }^{77}$ who had recently experienced 'unconventional' methods of anti-guerrilla warfare in Indo-China. After the humiliating and crushing defeat of the French army at Dien Bien Phu (7 May 1954), and the subjection of 12,000 prisoners to techniques of brainwashing and communist indoctrination, military theorists began the process of examining the hard lessons to be learned from IndoChina and how these could be applied to colonial warfare in Algeria. Most of the key exponents of psychological warfare were inspired by a virulent anti-communism and an apocalyptic vision of a global communist encirclement of the 'west' through support for anti-colonial and Third World struggles for independence. Faced with this mortal threat military strategists like General Chassin argued that the French army must adapt to the new kinds of totalitarian warfare developed by the enemy: 'The time has come for the free world, unless it wishes to die a violent death, to apply certain of its adversary's methods' ${ }^{78}$

The key idea, and indirectly the most relevant to the position of Algerian women, was drawn from Mao Tse-tung's work on the strategy of revolutionary warfare (1936) in which guerrilla forces could best survive, like fish in water, when they found logistic and moral support from the people: 'But if you drain the water or a drought should come, then the fish dies or disappears'. ${ }^{79}$ From the very first shots of the insurrection in the Aurès mountains on 1 November 1954, the War of Independence, despite its dramatic urban dimensions, was primarily a war of guerrilla fighters in the mountainous interior who could not have survived without the support of the peasantry, and primarily of women, who supplied them with food, accommodation, clothing, medical aid and intelligence. In reality, as we will see, such support was never a simple matter, a question of the spontaneous and automatic resistance of an oppressed people, but had to be gained and constantly sustained by the ALN through its political organisation, the Organisation politicoadministrative (OPA), and traditional or tribal leaders, propaganda, social work, 'revolutionary justice' and terror. The French specialists of revolutionary warfare proceeded from the idea that it was crucial to 'drain the swamp', to remove the support base of the relatively small number of guerrillas among the peasantry, by winning the mass of the population over to the French side, by protecting them from ALN terrorism, and eventually forming villages into armed auto-defence units that could take on the enemy and guarantee safe-zones in which the 'civilising' mission of schooling and economic reconstruction could continue. Essentially warfare was seen as a 'total' phenomenon, not simply a question of guns and armed conflict, but a matter of fighting for the hearts and 
minds of entire populations, a battle that reached far into every aspect of everyday 'civilian' life. From late 1956 onwards counter-insurgency officers and specialist advisers began to recognise that such an agenda could not afford to neglect women, half of the total population.

The key phase in the penetration of the doctrine of psychological warfare into all levels of the military and civilian government hierarchy came, under the aegis of the Minister of Defence and later Prime Minister, Maurice Bourgès-Maunory, between July 1956 and August 1957, culminating in the creation of the Fifth Bureaux. ${ }^{80}$ A significant moment was reached with the creation of a body of officiers itinérantes in July 1956, all of them former prisoners of the Viet Minh camps, who were attached to commanders in the field so as to lead, 'a vast campaign of disintoxication and re-education of the Muslim population'. ${ }^{81}$ But the key turning point came immediately after the Suez debacle on 5-6 November 1956 with the appointment of the Vietnam veteran, Raoul Salan as commander in Algeria. Salan brought with him a team of specialists in counter-insurgency, including Colonels Trinquier and Goussault, who played a role in elaborating subversive actions aimed at Algerian women. ${ }^{82}$ By August 1957 the Fifth Bureau had established a structure that reached through all levels of the army command, a 'biérarchie parallele' that studied, prepared and implemented propaganda and counter-insurgency actions. ${ }^{83}$ This organisation came to exercise, partly through its officer training centres at Arzew and elsewhere, a powerful ideological hegemony throughout the forces, and began to develop proto-fascist and far-right Catholic theories that encroached dangerously into the sphere of politics. It was with the arrival of Salan and Goussault in December 1956 that we see the first clear, although highly secret, signs of a new programme directed specifically towards women.

A key objective of Lacheroy and other officers of the Fifth Bureau was how to deploy counter-revolutionary warfare to win the hearts and minds of the Algerian population. In such forms of non-conventional warfare intelligence not only about the FLN but also about the attitudes and morale of the ordinary people was crucial to the design of propaganda and other measures, from welfare to education. As Stathis Kalyvas has noted, civil wars in which there are no front lines, and in which insurgents may be present but 'invisible' in the civilian population, present a particular 'identification problem' to occupying forces. Local populations, fearing terrorist retribution, may refuse to identify combatants hiding among them, a situation which leaves the security forces highly vulnerable. ${ }^{84}$

The French army, faced with this problem, resorted to a combination of methods, from deployment of paid informers to systematic torture, but the approach that is of most interest here involved a 'strategy of 
contact', the creation of organisations that could build bridges between the much feared army and a civilian population that remained stubbornly silent and hostile. The French colonial army had a long experience of such so-called rural 'pacification' methods, the elaboration of welfare and health programmes in tribal or peasant societies, that would simultaneously win the trust of the population and enable sound intelligence to be gathered. The outstanding example of such a specialist organisation during the Algerian War was the SAS set up by Soustelle in 1955, but by late 1956, in line with the emergence of a women's emancipation agenda, the army was tentatively exploring how to establish methods that would enable 'contact' with Muslim women. Such an agenda posed formidable problems in the bled, the rural interior in which 80 per cent of all Algerian women lived, the zones that served as the base of the FLN maquis. How could a strategy of contact be created for that half of the population that was radically segregated and isolated from the public sphere behind the walls of the home? It was this challenge that was first addressed during 1957 by the ethnologist Jean Servier, in a secret experiment code-named Operation Pilot that proved to be so successful that it came to provide the standard model for counter-insurgency 'pacification' for the whole of rural Algeria until the end of the war. Servier appears to have been the first person during the war to design a military programme that was directed specifically at peasant women.

Jean Servier, a pied-noir ethnologist, carried out fieldwork during 1949 and 1954 for a doctorate on the different Berber peoples of Algeria, and his linguistic skills and knowledge of Kabylia, an area of intense growing nationalism and banditry, was of political interest to the Algiers government that funded and commissioned him to prepare reports in 1952-53. ${ }^{85}$ It was by chance that Servier was carrying out fieldwork in the Aurès mountains, the epicentre of the insurrection, on 1 November 1954. He achieved considerable publicity and fame because of his rescue of the wounded teacher Mme Monnerot from a bus ambushed by the FLN, and for his defence of the besieged town of Arris through the distribution of fifty rifles to the first improvised harki unit of the war. ${ }^{86}$ This Beau Geste moment brought the young ethnologist to the attention of Soustelle, ${ }^{87}$ and after the presentation of his thesis at the Sorbonne in $1955,{ }^{88}$ Servier was recruited by the army. He received training in Paris during the spring of 1956 from Colonel Goussault, later head of the Fifth Bureau, in revolutionary and psychological warfare, and in turn taught courses to SAS officers at the Centre militaire d'information et de spécialisation pour l'outre-mer (CMSIOM). ${ }^{89}$

From March to August 1956 Servier was, as chargé de mission aux affaires politiques, closely associated as a specialist adviser during 
the planning of one of the most secret and controversial operations of the Algerian War. The aim of Operation K or Opération Oiseau Bleu was to create and arm a 'Third force' counter-maquis among the tribes people of the Iflissen, whom Servier had studied in 1952-53. ${ }^{90}$ Operation $\mathrm{K}$ turned out to be a bloody catastrophe for the French army since the maquis which it armed and supported was pro-FLN and in a counter sting operation inflicted heavy casualties on a French unit during an ambush on 1 October 1956. ${ }^{91}$ Despite this débâcle Servier's credit remained sufficiently high with the army command for him to be placed in charge of a second clandestine Operation Pilot in January 1957. Operation Pilot is of particular interest since this experimental counter-insurgency operation was particularly focused on Algerian women and led to the establishment of the single most important wartime initiative to reach out to Muslim women, the EMSI. In late 1956 Servier was in Paris when he read a newspaper account of how the peasants of Bou Maad, located in the Dahra Mountains to the north of Miliana, had revolted against the terrorist grip of the FLN and had handed over money collectors to the gendarmerie. ${ }^{92}$ Servier, who knew this area well from his fieldwork in 1949 and 1950, was so excited by this potential for breaking FLN power in the bled that he left immediately for Algiers and submitted to the Minister, Lacoste, a proposal that General Salan called, 'an in depth action for the reconquest of the population'. ${ }^{93}$

Servier's timing could not have been more propitious: Salan, newly arrived as commander of the combined forces in Algeria in December 1956, brought with him a circle of ex-Vietnam veterans who were dedicated to the techniques of revolutionary warfare, and who were prepared to experiment with daring and unconventional methods. At the same moment General Massu, on assuming both civilian and military powers on 7 January 1957, unleashed the massive operations known as the 'Battle of Algiers' to root out the FLN terrorist networks in the capital. The same month saw the creation of the Fifth Bureau, headed by Colonel Goussault, and so everything was pointing to a radicalisation of the war. It seems likely that it was Goussault who arranged a meeting between Servier and General Salan on 16 January to agree a plan that was strongly opposed by the conservative 'Grands Services' of the General Government who were shocked by a project that went against the policies they had followed for years. ${ }^{94}$ Salan gave the green light and the next day summoned the military and civilian heads of the Orléansville region, General de Brébisson and the Prefect Chevrier, to brief them on 'Pilote 1', which was planned to take place in their area of command between 26 January and 26 March. $^{95}$ 
The genesis of Servier's thinking on emancipation can be traced back to August 1956 when he had been working as chargé de mission under Lucien Paye, Directeur des affaires politique, ${ }^{96}$ at the very moment that Lacoste's cabinet was turning to the implications of Bourguiba's radical Code of Personal Status. The ethnologist had a close knowledge of the way of life of peasant women in the most isolated mountain zones, and was in a good position to formulate policy. ${ }^{97}$ On the 12 August Servier sent Paye two reports from the army HQ in Tizi-Ouzou, where he was involved in the 'Oiseau Bleu' operation, one of them a Note sur le Statut de la Femme Kabyle. Bourguiba had first announced the new Tunisian code in two speeches on 3 and 10 August, and it seems likely that Servier was responding to this news when he wrote to his director, Lucien Paye, who several months later was to sit on the working party for the revision of the Algerian law on marriage and the family.

Servier argued in his paper on the personal status of Kabyle women that they were subject to the patriarchal group and 'remain minors in law ... They cannot participate in the public life of the village. They are neither voters nor electable and are not allowed to give witness before the village assembly (djemâa)', and given present conditions, 'it would seem unwise to change radically the status of women'. ${ }^{98}$ However, he noted that Kabyle peasants were favourable to the education of their daughters, but were held back by the fear of dishonour and disapproval of conservative society and what neighbours might say. The answer to this was for the government to impose universal schooling on all girls, a step that Kabyles would welcome. In addition, he predicted a coming offensive of the FLN against French schools: 'It is likely that the FLN will undertake the initiative of an obligatory Koranic education of girls from October [1956] as part of its offensive against the French school'. Servier outlined a counter-programme:

The teaching of girls should be practical and based on domestic skills and child- care that take as their point of departure what one finds in a normal Kabyle house ... The place of the Kabyle women within the household, her role in overseeing the home and the education of children, means that the day that the 'old Matriarchs' - the elderly mothers of the husbands are replaced by the pupils of the French school, Kabylia will tip over as a block into western civilisation. This evolution can only occur if France, in a first phase, seeks to form the future mistresses of the house rather than to transform those who stay squatted round the hearth.

This recommended programme was very similar to the approach that was taken a year later by the EMSI teams. ${ }^{99}$ Servier announced what was to become a central tenet of military-led emancipation, that since 
women constituted the very bastion of Algerian-Muslim identity, culture and tradition, and its point of reproduction, a key aim of psychological warfare must be to intercept and re-shape this habitus.

Early in 1957 Servier set out his ideas for propaganda activity with women in a further document, Définition d'une idéologie pour les Operations 'Pilote'. ${ }^{100}$ It announced the idea of a 'New Algeria', emerging truly free and modern, struggling against the privileges of the ruling elite of grandes familles and caïds; against the prejudices imposed by backward customs and religious traditions that had no foundation in the Koran; and against the: 'subjugation of the woman that maintains her in a veritable state of slavery when in every modern country the woman is today free to live as she chooses, to dress as she wishes, to go out, and to work outside the confines of the house'. The concept of an 'Algérie Nouvelle' was developed in a further directive which advocated a 'religious emancipation' from the cadis and Ulemas, allies of the FLN which forbade the education of children, and deliberately kept the people in ignorance in order the better to oppress them and extort money. ${ }^{101}$ This reflected Servier's discovery from his earlier ethnographic fieldwork that the PPA and later the FLN had penetrated secretly into the most isolated mountain areas during the 1950s in the form of a Ulema puritanism, which he detested. ${ }^{102}$ Servier forecast that FLN 'cultural commissars' would in a first stage make use of marabout prestige to gain influence over the masses and to preach a holy war (jihad), but since they were former pupils of the reformist médersas they would in a later stage break the privileged position of the marabouts castes and force attendance at Koranic schools in which Arab language and culture would displace both Berber and French. Servier proposed blocking this pan-Arab hegemony by ensuring that the zaovias taught a modern French curriculum that would also be able to prepare the way for female emancipation. ${ }^{103}$

The Pilot directive, under the rubric Emancipation de la femme, 'Insists on the fact that in modern society all beings are equal: women are and must be the equal of men'. It attacked the barbaric practices supported by Muslim law, by which 'the husband can beat his wife, deprive her of food, and repudiate her by pronouncing a simple formula'. The Muslim woman was treated as a slave, 'a beast of burden', and, 'as a victim of archaic prejudices, is kept isolated from society. From the age of puberty she can no longer go out except when accompanied'. As a result girls did not go to school, were closed to any idea of progress, were ignorant of basic principles of hygiene, and used the most traditional methods in the home, preferring the wood-fired stove (kanoun) to Butagas or paraffin cookers. Other Islamic states like Turkey and Tunisia had shown that modernisation was perfectly compatible with religion. ${ }^{104}$ 
So much for Servier's general ideas on emancipation, but how did this strategy of contact translate into practice on the ground? The idea behind Pilot was to target a particular isolated zone, in this case the mountainous area of the Dahra between the Chélif River valley and the coast, an area defined by the quadrilateral between Orléansville, Ténès, Cherchell and Miliana, an 'infested corner' where the FLN had established a solid military and political structure (OPA). The Dahra, without roads, was so cut-off from the European-dominated plains that there was almost no French presence, administration or infrastructure. One area within the Pilot zone, the military operational sector of Ténès, spread over 2,000 square kilometres, in early 1957 had only two civilian and four army doctors for a population of 115,000 people.

The initial problem facing the army was that FLN terrorism, able to wreak rapid and deadly force against 'collaborators', held the inhabitants in a vice-like grip, so that no intelligence was forthcoming nor any degree of co-operation, even in the case of reforms that might be beneficial to the population. The strategy of 'pacification' of the region was to take place in two phases, summarised as 'destroy and build': firstly, the army would engage in a major offensive to locate and destroy the ALN forces, and then move rapidly to assure protection to the population from FLN terrorism, a crucial precondition for the establishment of a new order in which Algerians would eventually begin to take on responsibility for running their own free society that would eliminate all nationalist influence. ${ }^{105}$ The second phase of Pilot, described as a 'work of in-depth pacification', represented an ambitious, 'essentially totalitarian' plan, in the sense that every aspect of local Algerian life would be radically transformed using, 'military, political, administrative, cultural, social and medical means'. ${ }^{106}$

The second phase, one of 'building contact', involved a co-ordinated team moving into selected villages in turn and a frequent initial response of the inhabitants was to flee, terrified, into the forests, but with time the reassured population began to appear. The team typically consisted of a protective military escort led by psychological warfare officers (officiers itinérantes), ${ }^{107}$ a mobile loud-speaker and cinema lorry (CHPT), ${ }^{108}$ small medical teams of army doctors and nurses (Service d'aide médicale gratuite or AMG), and the proto-type EMSI, small 'mixed' units made up of one European woman and one or two Muslim assistant-interpreters or Adjointes sanitaires et sociales rurales auxiliaires (ASSRA), who had the specific task of making contact with Muslim women. ${ }^{109}$ A typical example of such initial contact comes from the Douar Drablia on the morning of 10 July 1957, when the inhabitants were summoned to attend a rally at which 150 men were placed in one group, and 170 
anxious women and children in another. After being harangued with anti-FLN propaganda, such as the slogan 'Don't let yourself be devoured by the jackals', one medical team treated the men, while a medical-EMSI team cared for the women. The people were invited to choose a spokesman from each fraction of the tribe and in the following discussion one man asked for weapons to defend the village against the FLN. When the EMSI team departed, the local women ran after the Muslim assistants to thank them. ${ }^{110}$

The action directed towards women was one component of a larger range of measures initiated by Servier's team in the Dahra. FLN prison labour and six bulldozers were used to rapidly build a network of dirt roads (pistes) that allowed rapid military intervention to protect villagers from FLN incursions. ${ }^{11}$ Servier took particular pride, as he had done in the Aurès in 1954, in arming and training harkis to form units (harkas) that protected villages (auto-défense) and tracked down FLN fighters concealed in the surrounding population. Schools that had been destroyed by the FLN were rebuilt and re-opened with great pomp and feasting. ${ }^{112}$ One of the most secretive parts of the operation was the plan to send hand-picked local men, including prisoners and those who had 'rallied' from the FLN side, to the counter-insurgency training school at Arzew where they were intensely trained, using methods drawn from Vietnam, as 'political commissars'. ${ }^{113}$ They were then discretely reintroduced back into the douars where they were to provide intelligence, keep watch on individual loyalties and recruit for the harkas. ${ }^{114}$ Servier's vision of the future seems to have been linked to Lacoste's 'Third Force' strategy and the important legislation of the loi cadre by which Algerians would themselves come to play a major role in the reorganised structures of elected local government, so building up a new participatory democracy from the grass-roots that would eliminate the enemy OPA. The political commissars would play a key part in establishing sufficient security to enable the inhabitants to elect local assemblies that were cleansed of any 'sleeper' FLN terrorists. ${ }^{115}$

During 1957, after the initial contact with village women, Servier took particular care to develop the EMSI teams, paying and equipping them from a special secret fund of 600 million (old francs) allocated to him by the Algiers government. ${ }^{116}$ Since few of the European women who were recruited to head each team could speak Arabic or Berber dialect and had little close knowledge of Muslim customs, it was absolutely crucial to attach to them young Algerian women who could serve as interpreters and cultural intermediaries (ASSRA). It proved difficult to recruit 'évoluées favourable to France', but psychological warfare officers, following on from their Vietnam experience, took an obvious 
delight in being able to use ex-FLN militants in this task, women who it was thought would know the enemy better than anybody. ${ }^{117}$ For example, the army captured a young FLN nurse, a former student and daughter of a cadi who, Servier claimed, had fallen into the hands of the ALN band of Si Mourad who used her as a sexual slave. Enraged by her experience, she proved easy to 'turn' and was readily recruited as an assistant, providing a model for the rapid engagement of other young Muslim women. ${ }^{118}$ The journalist Jean Piverd described in glowing terms his departure for a two-day tour of villages 'into the outback', with a team of four, a doctor, a driver and Denise B., a twenty-five-yearold woman who had previously been a secretary in the Paris Ministry of Defence, and Touria B., an eighteen- or nineteen-year-old Muslim who, it was claimed, had been forced into an FLN unit where she had served as a nurse for nearly a year. ${ }^{119}$ Touria's ambition was now to train for a diploma in a school for ASSRA being built by Servier. ${ }^{120}$ As the team arrived in each village Piverd described the enormous crowds of people who queued up with every possible kind of malady, from purulent eye disease to infected cuts, and the EMSI paid particular attention to child-care, cleaning, bathing and weighing babies.

Piverd's report on the EMSI, which emphasised the heroic selfsacrifice of young French women in harsh and dangerous conditions, was to become one of the favourite subjects of army propaganda through the rest of the war, and endless photographs and films recorded smiling, blond and white-coated assistants tending to the needs of grateful peasant women and their babies. ${ }^{121}$ The outstanding example of such hagiography was Christiane Fournier's, Les EMSI: des filles comme ça!, which includes a photograph of hundreds of women and children seated on the ground waiting their turn, with the caption: 'A crowd that has descended from the four corners of the djebel, prisoners of an anachronistic Middle Ages, reach out towards a better life'. ${ }^{122}$ Servier claimed that in some villages the women had begun to form their own committees and, with army assistance, to initiate various self-help projects such as weaving carpets for sale in local markets. ${ }^{123}$

How successful was the first Operation Pilot, and the EMSI in particular? Internal army reports are rather contradictory, and reveal major and damaging internal battles over the operation between different branches of the civil and military hierarchy. Relations between General de Brébisson and the local Prefect Chevrier were strained, and the project was plagued by the lack of a coherent and unified command, so that it suffered from disputes between different 'fiefdoms' over personnel, funding and decision-making. Colonel Ameil, commander of the sub-sector of Orléansville was sceptical about the project from the 


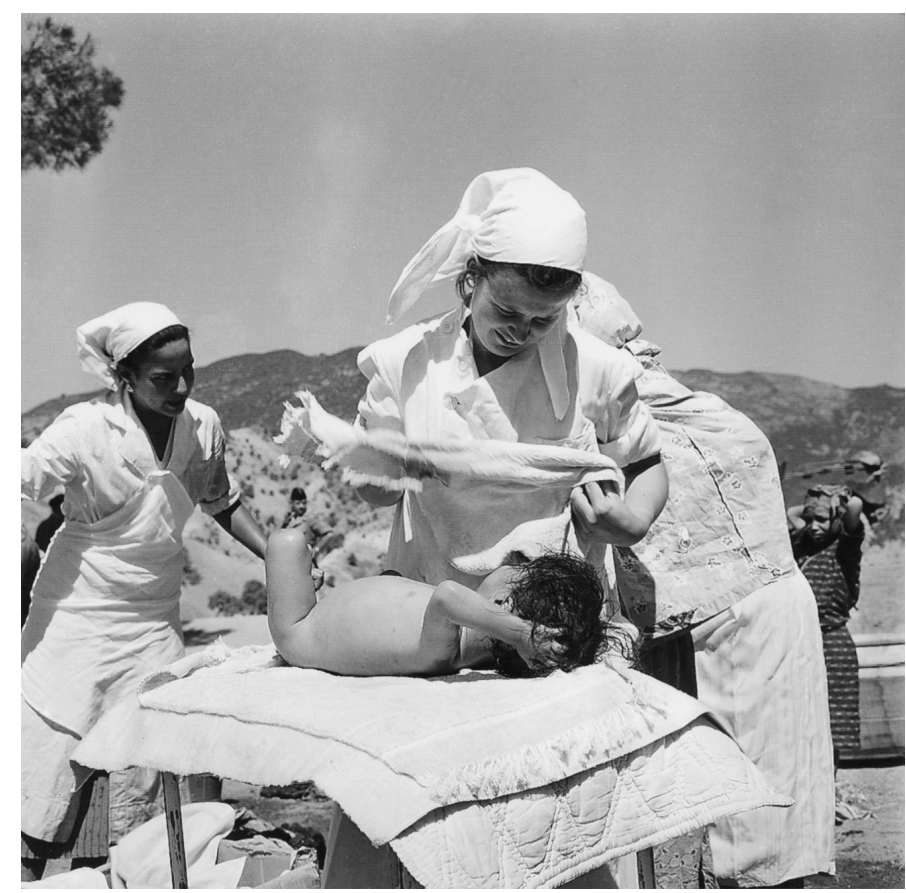

1 One of the early EMSI teams during Operation Pilot at Bou Maad, 1957

beginning, and later refused to support psychological actions, the EMSI or Arzew training programme, an opposition which led to his posting back to France. ${ }^{124}$ It seems likely that this opposition was a reflection of the hostility of some 'conventional' officers to the growing penetration and influence of Goussault's Fifth Bureau into the army command, and by early summer Goussault, following a tour of inspection, was livid at the failure to expand Operation Pilot into zones that were in the original plan, and demanding to know what commanders had done with the considerable resources in extra manpower and materials allocated to them under Pilot.

From early March onwards General de Brébisson and General Allard, commander of the Corps d'armée d'Alger (CAA), marginalised the Servier operation by developing their own agenda, and rapidly extending the experiment into the departments of Algiers, Médéa and Mostaganem, ${ }^{125}$ and in particular as Operation NK-3 in the Palestro area. A series of top-level meetings had to be called in the Government General to sort out the seething discontents (13 May and 29 May), and Salan instructed Allard in June that any further extension to Pilot would 
need to be based on a detailed plan approved by Lacoste. ${ }^{126}$ Goussault wisely, if opportunely, decided to halt his criticism of the powerful army commanders, unlike Servier who, standing outside the conventional military hierarchy and endowed with a sense of his superior mission, had no hesitation in circulating withering criticisms of both Goussault and the generals. Among Servier's criticisms of the army command was the treatment of harkis as second rate mercenaries, lacking proper pay and conditions, and the failure to see that revolutionary warfare did not consist of 'pure and simple brutal repression, that is to say, in most instances, blind, collective and unintelligent', a comment that has been marginally annotated in red crayon, 'idiot'. ${ }^{127}$ Servier, whose concerns seem well founded, ${ }^{128}$ recognised the central contradiction of army 'pacification', that indiscriminate violence and repression fatally undermined any 'good works' achieved by SAS and EMSI to win the hearts and minds initiative. It seems not too surprising that the outspoken Servier was sidelined to a meaningless desk job in the General Government and soon returned in April 1958 to an academic post in the University of Montpellier. ${ }^{129}$

The instability and in-fighting surrounding the Operation Pilot clearly damaged the outcomes of the programme during 1957, and, along with it, the creation of the first EMSI. The teams lived a handto-mouth existence, were lacking in adequate and secure funding, and by July the ASSRA under Mme Guilles had still not been paid. The colonel in charge of the army medical service was sabotaging the work of the EMSI, either by attaching them to his own service, or, instead of providing them with decent accommodation, posted them to live under tents in dangerous zones where they could not carry out their welfare mission. ${ }^{130}$ Opinion on the success of the EMSI was divided: in May General Huet was lavish in his praise of their 'excellent work' and seeking further sources of funding, but good results depended on the overall degree of security established in their zone of operation. In some areas the FLN made a sustained push to re-enter zones from which they had been driven, and in some instances cut the throats of local women who had provided water to French soldiers. ${ }^{131}$ In December one colonel noted, after an initial positive response to the EMSI, a deterioration in the climate owing to FLN pressure: assistants were badly received, and local women said they had no need for medical or other help, which was patently untrue. The loud-speaker lorries (compagnie de haute-parleurs et de tracts, CHPTP) were greeted with a 'hint of scepticism and irony', and the commander concluded that despite six months of psychological campaigning by Pilot, 'the hold of the rebel OPA is still strong in regions considered to have been pacified'. ${ }^{132}$ 
But overall the EMSI proved sufficiently successful for the experiment to be extended, and the five initial teams, ${ }^{133}$ had by August 1957 been expanded to eleven, three based at Orléansville, two at Miliana, three at Cherchell and three at Ténès. Lacoste, by an order of 25 October 1957, then extended the system to the rest of the colony, and a special induction course was set up in Algiers. ${ }^{134}$ Among the key factors that inspired the high command to expand and generalise the EMSI, as will be seen (chapters 4 and 7), was the realisation of the propaganda advantages to be won via the international media, the lure of intelligence to be won by penetrating the intimate world of the Algerian family, and the advantages to be gained from seizing the initiative on emancipation that out-manoeuvred the FLN which, for religious and political reasons, was unable to support a progressive agenda for women. ${ }^{135}$

\section{Urban counter-insurgency: emancipation and the 'Battle of Algiers'}

The final factor that led the Algerian government and military to advance an emancipation strategy was the growing awareness that it needed to pre-empt the FLN, which was developing a similar agenda. The guerrilla forces of the FLN had from the very beginning of the war received the crucial logistic support of peasant women who cooked, washed clothes, acted as look-outs and concealed the fighters, but such support, the 'natural' domestic role of mothers and sisters, was rarely if ever acknowledged by either side in the war. However, during the course of 1955-57 the FLN began systematically to recruit educated young women from urban society either to serve as nurses in the maquis or as liaison agents in the terrorist networks. The role of Algerian women within the FLN structure will be examined in detail in chapter 9; here the aim is to consider the process by which the French army became aware of this growing involvement and reacted to it.

Army officers, who entertained Orientalist assumptions of Muslim women as veiled and timid beings, lacking in any initiative, subservient and crushed under the boot of male power, were astonished by the growing number of Algerian female militants caught in 1955-56 during military operations. Between June 1955 and the end of 1956 some twenty-eight women were arrested for transporting weapons and ammunition and housing FLN militants, but the biggest shock came after the first arrest in July 1956 of three nurses in the maquis and the realisation that women were now serving with ALN guerrilla forces. ${ }^{136}$ Doctor Nefissa Hamoud, an Algiers paediatrician and the first woman to go regularly into the Kabyle maquis to provide medical aid, was arrested 
in an ambush in October $1956 .{ }^{137}$ Documents found on the body of an FLN political cadre killed on 4 October 1957 indicated that Algerian women were serving as armed combatants in the North Constantine area, after receiving medical training in early 1957 . At the very moment that the first EMSI experiment was underway in Operation Pilot, the women fighters in the ALN were taking on an identical function as political propagandists and as 'veritable social welfare assistants in the service of Algerian women'. ${ }^{138}$

However, the biggest shock for the French came during the 'Battle of Algiers' of 1956-57 when Massu's parachutists arrested a number of young women who were closely involved in the transmission of messages, guns and bombs for Yacef Saadi's terrorist network. ${ }^{139}$ The centre of gravity of the rebellion may have been in the bled, but during 1956-57 the world media turned with fascination and horror to the stories of Zohra Drif, Djamila Bouhired, Samia Lakhdari, Djamila Bouazza and others who planted bombs in the milk bars of crowded Algiers from September 1956 onwards. It was the female urban terrorist, later depicted in Gillo Pontecorvo's remarkable 1965 dramadocumentary The Battle of Algiers, that provided the most powerful and enduring image of Algerian women's new-found capacity to defy convention and assume a new role as nationalist militants and fighters.

The involvement of young women in the FLN networks of Algiers had become clear to the French authorities some time before the bombings, most notably through the lycée and student strike of May $1956 .{ }^{140}$ The army was increasingly preoccupied with the problem of how to penetrate into, and gain intelligence on, the FLN networks that found a bastion within the warren of the ancient Casbah. It was precisely at this moment that signs first appear of the army trying to engage in a 'strategy of contact' with Muslim women through the manipulation of the Centres sociaux.

The military were fully aware of the extent to which the dedicated and idealistic social workers of the Centres sociaux, through their welfare work in the bidonvilles, had built up close relationships and trust with the urban poor, a source of contact that could potentially provide a mine of intelligence. A first sign of military attempts to intrude onto the terrain of the social workers came on the night of 26-27 May 1956 when the police and army mounted a huge operation to surround the Casbah, a key fortress of FLN militancy, during which over 4,000 men were arrested. On the 26 May all eighty social workers in Algiers were assembled by order of the head of the public health services, divided into ten teams, and asked to go in police lorries to carry out an unknown task. When they discovered that they were expected 
to unveil and frisk Muslim women to make sure they were not FLN men in disguise or carrying weapons, the team of eight led by Marie Chéné, and half the team of Emma Serra, refused and were threatened as 'traitors' and held in lorries or police cells overnight. On the 28 May Chéné wrote to the Association nationale des assistants socials (ANAS) in Paris, complaining that, 'our mission as social workers will be seriously compromised through participation in this policing operation'. ${ }^{141}$ The national president of the ANAS, Mlle de Laage, managed to gain a retraction from Lacoste and the Paris government and a recognition that the action had breached the professional and legal code of social workers. However, the crisis revealed a serious split within the corps of assistants and a majority, perhaps mainly pieds noirs favourable to Algérie française, wrote to Lacoste opposing the ANAS, claiming that the police mission assigned to them was not incompatible with their professional ethic, particularly under the exceptional conditions in Algeria, and that it was proper 'to humanise the system of control'. ${ }^{142}$ Mme R. Bley, head of the Service social familiale nord-africain in Paris, who was shocked by this 'regrettable state of mind', was to find herself during 1961 in the forefront of opposing a similar onslaught on the social services by Maurice Papon's police before and after the massacre of 17 October. $^{143}$

Despite the Algerian government's retreat on this issue in May, the writing was on the wall, and increasingly through 1956-57, especially with the 'Battle of Algiers', the police and army moved to interfere with, or control, the work of both the Centres sociaux and of the social work teams established by Scotto. However, despite enormous pressure and intimidation, the authorities largely failed to harness the centres as auxiliaries to their repressive agenda. The army then adopted a quite different tactic and began publicly to denounce them as hot-beds of FLN sympathisers and arrested, tortured or expelled them back to France. Annie Steiner was arrested as early as 15 October 1956 and sentenced to five years in prison; Hélène Gautron was arrested on 21 February 1957 and tortured; Nelly Forget, a SCI militant, was arrested on 5 March 1957 and tortured; and eventually thirty-five liberals appeared in a kind of 'show trial' on 23 July 1957. A virulent campaign in the Algerian press made the Centres sociaux a target of pieds-noir hostility and led eventually to the murder by the Organisation armée secrète (OAS) of six leading members, including the writer Mouloud Feraoun, on 15 March 1962. ${ }^{144}$

The history of the Centres sociaux during 1956-57 indicates how the security services were becoming increasingly interested in the processes by which a 'strategy of contact' could be constructed and developed, 
especially in order to penetrate the segregated universe of Algerian women. When they found the professional social workers, who were supported by their national association, resistant to such manipulation, the army went ahead and began to develop its own parallel institutional base for such an initiative, particularly through the creation of women's local associations or circles that expanded dramatically after '13 May 1958 '.

The single event, however, that galvanised the army to accelerate an emancipation agenda arose from the final capture on 26 August and interrogation of Zohra Drif, the outstanding woman member of Yacef Saadi's underground. The intelligence service was able to capture documents that revealed Drif's advanced plan to set up a totally new clandestine organisation for women based on the classic secure form of cells of three arranged in a hierarchical pyramid. During her interrogation on 2 October Zohra Drif, who remarked, 'I insisted on the importance of the social role of women', revealed how she intended to organise a team of women in each Algiers quarter which would provide medical and social aid for poor families, support the families of FLN prisoners, engage in propaganda through tracts and demonstrations, serve as liaison agents and collect intelligence on French informers. ${ }^{145}$ This structure, which seems to have been in part modelled on the cells of the former PPA Association des femmes musulmanes algériennes, would have included 357 women in all. Identification and recruitment of 'sisters' was already under-way when Drif was arrested, and since it had been particularly difficult for the army to search or arrest veiled Muslim women liaison agents the proposed network offered a formidable potential for the regeneration of the Zone autonome d'Alger (ZAA) that had been decimated by army repression.

The high command, including Generals Salan and Allard, took a keen interest in the discovery of this previously unknown plan, and intelligence analysts reported, 'Such an organisation constitutes in the hands of the rebels a powerful means to control the Muslim popular masses. On these grounds, it merits our fullest attention'. From this moment the army and civil administration began to pay particular attention to, and collect intelligence on, the role of women within the FLN organisation. ${ }^{146}$ From the summer of 1957 onwards the Fifth Bureau had organised a series of propaganda radio broadcasts on the theme of unveiling, and the modernisation and liberation of Algerian women (see chapter 3). The army placed letter boxes in the Casbah in which Algerians could discreetly put messages to the authorities: one such anonymous letter dated 8 April 1958 from a woman expressed appreciation of the 'Radio Casbah' broadcasts against veiling, and claimed that for Muslim women 
to become modern and civilised it was necessary to ban the veil, 'that suffocates her, that hinders her in work or education . . . and which above all deprives her of liberty and imprisons her between four walls'. General Massu forwarded this letter to Allard, noting this sign of, 'the aspiration of Muslim women for rapid progress'. He argued that the veil should be banned immediately and, 'I have already had occasion to express my fear of seeing us outdistanced in this area by the FLN that could advocate a similar radical transformation of customs, with guaranteed good results'. ${ }^{147}$

By the winter of 1957-58 the military were impressed by the results of their own emancipation strategy achieved during Operation Pilot, but they had become simultaneously aware of, and disconcerted by, the extent to which the FLN was also harnessing the enormous potential of women to the nationalist struggle. Until this moment most aspects of the army's highly secretive emancipation agenda in the Dahra and elsewhere remained unknown to the public. While the Fifth Bureau had covertly utilised propaganda by radio, film and newspapers to try and change, or gauge public opinion on female liberation, as in Difrane's Figaro articles, the government was not able to gain any prestige among the Muslim population or international opinion for its still secretive emancipation campaign. The discovery of Zohra Drif's detailed plan for a woman's clandestine organisation made clear the very real danger that the FLN might seize the initiative, and trump the army. On 6 May 1958, General Allard, a key advocate of psychological warfare, forwarded Massu's letter to Salan, noting:-

The action undertaken in relation to women for over a year by the free medical teams, by the women's circles, and through propaganda, has obtained un-hoped for results.

The time has come to go officially public on the emancipation of Muslim women so as to prevent the rebels from profiting from the current change in the state of mind brought about by us through so much effort. ${ }^{148}$

Exactly one week later, on 13 May 1958, the military coup by the Generals in Algiers provided the ideal conditions for the achievement of this goal, the launching of a co-ordinated and open campaign for emancipation.

\section{Notes}

1 Much confusion has been caused by the practice of using the date of 13 May to refer to both that specific day, as well as to the overall three-week crisis: I 
have used 13 May (no quotes) to refer to events on that day alone, and '13 May' or the 'journées of 13 May' (in quotes) to denote the entire phase of the crisis that ended with De Gaulle's inauguration on 1 June.

2 Amrane, Les Femmes algériennes, 221-2; Kessel and Pirelli, Le Peuple Algérien, 130-4: Safia Bazi, Fadila Mesli and Meriem Belmihoub were not the first women captured in the maquis, but did trigger a huge media interest.

3 The shift towards an emancipation agenda during late 1956 and early 1957 did not come about through a clear policy initiative made centrally by the government and army, and there exists no documentary evidence for this in the archives. Rather, the change can be deduced from a sequence of initiatives or actions 'on the ground' that appeared about the same time and reveal that the issue of emancipation was widely diffused.

4 Shafer, Deadly Paradigms; Gendzier, Managing Political Change; Christopher Simpson, Science of Coercion. Communication Research and Psychological Warfare, 1945-1960 (Oxford: Oxford University Press, 1994).

5 Connelly, Diplomatic Revolution, 27-38; and 'Taking Off the Cold War Lens: Visions of North-South Conflict during the Algerian War for Independence', The American Historical Review, 105 (June 2000), 221-45; Paul and Marie-Catherine Villatoux, La République et son armée face au 'péril subversif'. Guerre et action psychologiques, 1945-1960 (Paris: Les Indes Savantes, 2005), 437, on the military use of Sorbonne specialists in sociology, propaganda, demography, etc., and on US counter-insurgency theory and the training of French officer at Fort Bragg, USA (1952-56), ibid., 188-95, 263, 363, 432.

6 On the background to planning for the Algerian economy between 1945 and 1958, see Lefeuvre, Chère Algérie, 240-348.

7 Ibid., 265, 267.

8 On the background to the fall of Mendès-France see Jean-Pierre Rioux, The Fourth Republic, 1944-1958 (Cambridge: Cambridge University Press, 1987), 225-40; Alexander Werth, The Strange History of Pierre MendèsFrance and the Great Conflict over French North Africa (London: Barrie Books, 1957).

9 On Soustelle and Algeria see Stephen Tyre, 'From Algérie Française to France Musulmane: Jacques Soustelle and the Myths and Realities of 'Integration', 1952-1962', French History, 20: 3 (September 2006), 276-96; James D. LeSueur, Uncivil War. Intellectuals and Identity Politics During the Decolonization of Algeria (Philadelphia: University of Pennsylvania Press, 2001); Todd Shephard, The Invention of Decolonisation. The Algerian War and the Remaking of France (Ithaca: Cornell University Press, 2006).

10 A detailed account is provided in Jacques Soustelle, Aimée et souffrante Algérie (Paris: Plon, 1956), 23-94.

11 Ibid., 83.

12 Ibid., 54.

13 Ibid., 88. 
14 Ibid., 138-42, 160-1.

15 Ibid., 26-7.

16 This neologism is taken from Mohammed Harbi, L'Algérie et son destin, 136.

17 For this in general Philippe Lucas and Jean-Claude Vatin, L'Algérie des anthropologues (Paris: Maspero, 1982).

18 Soustelle, Aimée et souffrante Algérie, 83; Denis Roland, 'Jacques Soustelle, de l'éthnologie à la politique', Revue d'Histoire Moderne et Contemporaine, 43: 1 (January-March 1996), 137-50; Grégor Mathias, Les Sections administratives spécialisées en Algérie. Entre idéal et réalité (1955-1962) (Paris: L'Harmattan, 1998), 24.

19 Comité algérien pour l'éducation de base, 10 June 1955, quoted in Nelly Forget, 'Le Service des Centres Sociaux en Algérie', Matériaux pour l'histoire de notre temps, 26 (1992), 45-6.

20 On the SAS, created by an order of 26 September 1955, see SHAT 1H2556/1; Mathias, Les Sections administratives; also Lieutenants Lasconjarias and Jouan, 'Les "Sections Administrative Spécialisées" en Algérie: Un outil pour la stabilisation', Centre de Doctrine d'Emploi des Forces, Ministry of Defense, 2005, located on the site www.cdef.terre.defense.gouv.fr (accessed 14 January 2009); on the Moroccan background see Jim House and Neil MacMaster, Paris 1961. Algerians, State Terror, and Memory (Oxford: Oxford University Press, 2006), 45-6.

21 On Louis Massignon see Edward W. Said, Orientalism [1978] (London: Penguin Books, 1987 edn), 264-74.

22 Vincent Monteil, Soldat de fortune (Paris: Grasset, 1966).

23 Ibid., 189. On Soustelle's conversion to a 'hard' repressive position see Wood, Germaine Tillion, 158-74.

24 Vincent Monteil, 'Essai sur l'Islam en URSS' and 'Supplément a l'Essai sur l'Islam en URSS' in Revue des Études Islamiques, 20 (1952-1953) (Paris: Paul Geuthner, 1953-4); General Tubert, L'Ouzbekistan, république soviétique (Paris: Édition du Pavillon, 1951).

25 Monteil, 'Essai sur l'Islam', 32-42; and 'La Femme libre', in Les Musulmans soviétiques (Paris: Seuil, 1957), 105-17.

26 Massell, Surrogate Proletariat; Northrop, Veiled Empire.

27 Monteil, Les Musulmans, 116-17. Soustelle notes, Aimée et souffrante Algérie, 87, that his inspiration for Algerian legal reform was in part drawn from Soviet and Yugoslav policy towards Muslim minorities.

28 Wood, Germaine Tillion, 'Humanisme éthnographique dans les Aurès: la mission Tillion/Rivière', 14-51; the volume of photographs by Germaine Tillion, with Nancy Wood, L'Algérie aurésienne (Paris: Éditions de la Martinière/Perrin, 2001); T. Rivière, Aurès/Algérie, 1935-1936 (Paris: Éditions de la Maison des Sciences de l'Homme, 1987), which includes an important essay by Fanny Colonna, 'Elle a passé tant d'heures. . .', 125-90; special issue 'Les Vies de Germaine Tillion', Esprit (February 2000), 82-169; Jean Lacouture, Le Témoignage est un combat. Une biographie de Germaine Tillion (Paris: Seuil, 2000). 
29 Tillion, France and Algeria, 24-5.

30 Germaine Tillion, Le Harem et les cousins (Paris: Seuil, 1966); translated into English as The Republic of Cousins (London: Al Saqi Books, 1983).

31 References here are to the English translation, Algeria, the Realities (London: Eyre and Spottiswoode, 1958).

32 Ibid., 18-22.

33 Chevalier, Le Problème démographique Nord-Africain; see MacMaster, Colonial Migrants, 184-6.

34 See Philip Dine's discussion, 'Ni victims ni bourreaux: The Liberal Dilemma', in Images of the Algerian War: French Fiction and Film, 1954-1992 (Oxford: Clarendon Press, 1994), 64-88.

35 See in particular Nancy Wood's excellent discussion of Jean Amrouche's critique of L'Algérie en 1957 in Germaine Tillion, 187-95; Wood has however (see Germaine Tillion, 44-51) significantly qualified Fanny Colonna's argument in Aurés/Algérie 1935-1936, 159-60, in which Colonna claims that Rivière and Tillion radically failed to identify the profound political and religio-nationalist transformations already evident in the Aurès during 1934-40, a failure of French ethnology in general, 'the collective aphasia of a dominant society faced with a reality that radically escaped it'.

36 Tillion, Algeria. The Realities, 29.

37 Ibid., 54, 58.

38 CAOM 12CAB192, 12CAB230, dossiers on Centres sociaux; Soustelle, Aimée et souffrante Algérie, 83-4; LeSueur, Uncivil War, 59-62.

39 For an important account of this little known enterprise see Dore-Audibert, 'L'action sociale', in Des Françaises d'Algérie, 41-80; Jean Scotto, Curé Pied-Noir, Évêque Algérien (Paris: Desclée de Brouwer, 1991); Forget 'Le Service', notes action also centred on the shantytown of Boubsila-Bérardi.

40 Forget, 'Le Service', 40, notes the role of other SCI workers, including Rachel Jacquet and Simone Chaumel-Tanner. The history and archival resources of the SCI, founded in 1920, can be located at www.sciint.org (accessed 14 January 2009). On the similar operations of the SCI in the shantytowns of Nanterre during the Algerian War, see Monique Hervo and Marie-Ange Charras, Bidonvilles (Paris: Maspero, 1971), and Monique Hervo's extraordinary memoirs in Chroniques du bidonville: Nanterre en guerre d'Algérie (Paris: Seuil, 2001).

41 On the growth of the Algiers shantytowns see Descloitres, et al., L'Algérie des bidonvilles.

42 Dore-Audibert, Des Françaises d'Algérie, 46.

43 Georgette Soustelle (1909-1999), like her husband, was a specialist on Mexico: her fieldwork in Lacandon in 1940-42 for a Sorbonne doctorate was published as, Taquila: un village nahuatl du Mexique oriental (Paris: Institut d'Ethnologie, 1958). In 1956 she provided the preface to, Boubsila, bidonvilles algérois. Étude sociale du bidonville de Boubsila dit Bérardi à Hussein-Dey, which suggests a close or 'patron' association with the Centres sociaux. 
44 Dore-Audibert, Des Françaises d'Algérie, 60, 72.

45 Forget, 'Le Service', 44-5.

46 On the February crisis and its significance see Alistair Horne, A Savage War of Peace: Algeria 1954-1962 [1977] (London: Macmillan, 1987 edn), 147-57; Sylvie Thénault, Histoire de la guerre d'indépendance Algérienne (Paris: Flammarion, 2005), 118-32.

47 By the decrees of 15-16 February 1956 the functions of the governor general were transferred to a délégué générale who was no longer under the authority of the Minister of the Interior, but of the Prime Minister assisted by a sécrétaire d'État aux Affaires algériennes.

48 Lefeuvre, Chère Algérie, quoting from Lacoste's speech to the Algerian Assembly, 21 February 1956.

49 Le Figaro 5 February 1957. SHAT 1H1147/1 file of press cuttings, shows that Difrane wrote several articles on emancipation for Le Figaro between 1957 and 1959, and later claimed (13 June 1959) that she was proud to be the first in the national press to break the 'taboo' on the subjection of Muslim women and to show that 'France has the right, the duty and the power to finally remove the barriers erected by a facile conformism'.

50 Soustelle, Aimée et Souffrante Algérie, 70.

51 J. N. D. Anderson, 'The Role of Personal Statutes in Social Development of Islamic Countries', Comparative Studies in Society and History, 13 (January 1971), 16-31, and Family Law in Asia and Africa (London: Allen and Unwin, 1968); Moors, 'Debating Islamic Family Law'; John L. Esposito with Natana J. Delong-Bas, Women in Muslim Family Law (Syracuse, NY: Syracuse University Press, 2nd edn 2001).

52 On the 'Bourguiba Code' see Mark A. Tessler, Janet Rogers and Daniel Schneider, 'Women's Emancipation in Tunisia', in Beck and Keddie (eds), Women in the Muslim World, 141-58; Susan E. Marshall and Randall G. Stokes, 'Tradition and the Veil: Female Status in Tunisia and Algeria', Journal of Modern African Studies, 19: 4 (December 1981), 625-46; Norma Salem, 'Islam and the Status of Women in Tunisia', in Freda Hussain (ed.), Muslim Women (London/Sydney: Croom Helm, 1984), 141-68; Charrad, States and Women's Rights; the most specialised and informed treatment is Borrmans, Statut personnel, Part 2, 275-421.

53 Borrmans, Statut personnel, 153-274.

54 La Condition de la Femme dans le Moyen-Orient Arabe (Paris: La Documentation Française, October 1955): copy consulted at CAOM $81 \mathrm{~F} 1219$.

55 An Inspecteur général de l'administration en mission extraordinaire (IGAME), was a kind of super-prefect who held special civil and military powers during periods of national emergency.

56 CAOM 13CAB7, Lacoste letter (secret), 5 November 1956; various documents and legal opinions on the Tunisian Code are in CAOM 12CAB207 and $81 \mathrm{~F} 1218$.

57 Salem, 'Islam and the Status of Women in Tunisia', 156. 
58 CAOM 12CAB207 Henry Le Breton, 'Note sur le Code Tunisian du Statut Personnel', undated, but probably just after September 1956.

59 CAOM 81F1219, Lacoste telegramme to Champeix, 25 April 1957; Champeix telegramme to Lacoste, 27 April 1957, informing him of the decision to consult a panel of legal experts.

60 CAOM 81F1219, minutes of the Groupe de Travail, 14, 20 and 27 May, 3 June 1957. Other members were Michel Rosier, Fusil, Ferrandi, Bauer, Casanova, Lucien Paye, Colombe, Colonel Pierre Rondot and Lefaucheux; further documentation from the Ministry of Justice can be located at the Centre des archives contemporaines (CAC) at Fontainbleau, see CAC 19950236, including Raymond Charles, Rapport préliminaire à l'avantprojet de code portant statut de la femme musulmane en Algérie, 7, which placed the need for reform within a broader context of codification in Morocco, Tunisia and elsewhere.

61 Copies of the Projet de réforme du statut personnel de la femme musulmane et de la femme Kabyle en Algérie, Ministry of the Interior, Direction des Affaires d'Algérie, June 1957, 142, are located in SHAT 1H112/3 and CAOM 14CAB165-6.

62 CAOM 81F1219, minutes, 14 May 1957.

63 CAOM 81F1219, minutes, 27 May, and 3 June 1957. Lefaucheux was in correspondence with the Figaro journalist Monique Difrane, who seized the opportunity to send a copy of her article, 'Indépendance en Algérie! Oui! Celle de la femme' to Simoneau, chairman of the working party.

64 See Connelly, Diplomatic Revolution, 92-3, on this major blow to French diplomacy.

65 Short History of the Commission on the Status of Women, 5-6.

66 CAOM 81F1219 contains much documentation on this issue, including UN resolution $547 \mathrm{H}$ (XVIII) of 12 July 1954, requesting all member states to assure women entire freedom of choice as to marriage partner, suppression of bride price, of marriage of pre-pubescent girls, etc. Forget, 'Le Service', 40, notes that the General Government was in June 1955 collecting data on the early Centres sociaux in preparation for a UN session.

67 CAOM 12CAB207. Opinion des IGAMES et préfets sur le problème de l'évolution de la femmes musulmane, Algiers, 3 July 1957.

68 On Papon and psychological warfare see House and MacMaster, Paris 1961.

69 Seferdjeli, 'French "Reforms”', 25.

70 CAOM 81F1224, Note on Projet de Loi, 1 July 1957; National Assembly, session 27 April 1956, and 16 June 1957; D. Sambron, 'Évolution du statut juridique de la femme musulmane à l'époque coloniale', in La Justice en Algérie. 1830-1962 (Paris : La Documentation française, 2005), 135-8.

71 CAOM 81F1218, Conseil de la République [Senate], 16 January 1958. Devaud, born in Constantine in 1908, married Stanislaus Devaud, elected deputy for Constantine in 1936. Active in the Paris Resistance, she was later Senator for the Seine from 1946 to 1958, and played a high-level national 
and international role in the women's movement, acting as French representative on the UN Commission on the Status of Women (1975-83): see http://annuaire-au-feminin.net/bioDEVAUD.html (accessed 11 June 2007).

72 CAOM 81F1218, National Assembly debate, 28 January 1958. Francine Lefébvre (1908-1979), was deputy for the Seine from 1946 to 1958.

73 On the formation of this progressive strata of bourgeois activists see Sylvie Chaperon, 'Feminism Is Dead. Long Live Feminism!', in Claire Duchen and Irene Bandhauer-Schoffman (eds), When the War Was Over: Women and Peace in Europe, 1940-56 (n.p.: Continuum International Publishing, 2000), 146-60; on Francine Lefebvre and the MRP see Patricia E. Prestwich, 'Modernizing Politics in the Fourth Republic. Women in the Mouvement républicain populaire, 1944-1958', in Kenneth Mouré and Martin S. Alexander (eds), Crisis and Renewal in France, 1918-1962 (Oxford: Berghahn Books, 2002), 199-220; Hilary Footit, 'The First Women Députés, "les 33 Glorieuses”?', in Harry Roderick Kedward and Nancy Wood (eds), The Liberation of France: Image and Event (Oxford: Berg, 1995), 129-41.

74 CAOM 12CAB207, National Assembly, 28 January 1958. An undated note, 'LIntégration et le statut personnel', stated in relation to the draft personal status law of June 1957: 'The Ministerial Cabinet has finally decided that this project will be left to the consideration of the local assemblies competent in the matter of "personal status".

75 SHAT $1 \mathrm{H} 246 / 1$ ", note, 'Action sur la femme algérienne', by Laperronieux [?], 18 May 1957, based on discussion with two officers of the Service des liaisons Nord-Africains.

76 There is a considerable literature on Algeria and 'revolutionary warfare', also referred to as 'psychological warfare': the fullest study is the joint doctorate of Paul Villatoux and Marie-Catherine Villatoux (University of Paris I, 2002), that has been published as La République et son armée face au 'peril subversive'. Guerre et action psychologique en France (1945-1960) (Paris: Les Indes Savantes, 2005). For an excellent short account see Peter Paret, French Revolutionary Warfare from Indochina to Algeria. The Analysis of a Political and Military Doctrine (London: Pall Mall Press, 1964); see also Paul Villatoux and Marie-Catherine Villatoux, 'Le 5e Bureau en Algérie', in Jean-Charles Jauffret and Maurice Vaïsse (eds), Militaires et guerrilla dans la guerre d'Algérie (Brussels: Éditions Complexe, 2001), 399-419; Mathieu Rigouste, L'Ennemi interieur postcolonial. De la lutte contre subversive au contrôle de l'immigration dans la pensée militaire française (1954-2007), doctoral thesis, Paris VIII, 2007.

77 Paul Villatoux, 'Le Colonel Lacheroy, théoricien de l'action psychologique', in Jauffret (ed.), Des hommes, 494-508.

78 General Chassin, 10 October 1954, quoted in George Armstrong Kelly, The French Army and the Empire in Crisis, 1947-1962 (Cambridge, Mass.: Massachusetts Institute of Technology, 1965), 24.

79 Villatoux and Villatoux, La République, 294, 312. 
80 Ibid., 369-71, 422-3, on Bourgès-Maunory's conversion to the doctrine espoused by Colonel Lacheroy.

81 Ibid., 228, 388-9: letter of R. Lacoste to commander 10th Military Region (Algeria), 5 July 1956.

82 Ibid., 422.

83 Ibid., 422-35, on the structure of the Fifth Bureau.

84 Kalyvas, Logic of Violence, 89-91.

85 CAOM 12CAB221: the GG provided Servier with official letters (3 April 1952, 9 January 1953) requesting sub-prefects, mayors and administrators to give him full assistance in the bled. The GG funded two payments of 150,000 AF each in September 1953 and June 1954, and commissioned research on the spread of Berber language.

86 On these events see Horne, Savage War, 88-93; and Jean Servier's account, Dans l'Aurès sur les pas des rebelles (Paris: Éditions France Empire, 1955), 7-29; for biographical details of his career see Maurice Faivre, 'Un Ethnologue de terrain face à la rébellion algérienne', Institut de Stratégie Comparée, www.stratisc.org/Faivre_7.htm (accessed 22 November 2005).

87 On Servier's background as an ethnologist see Jacques Cantier, 'L'Ethnologue et les savoirs autochtones: Jean Servier et les Berbères d'Algérie, étude de cas', Outre-Mers. Revue d'histoire, 352-3 (December 2006), 47-56.

88 Servier's original thesis has been lost (personal communication of Fanny Colonna), but was published as Les Portes de l'année, rites et symboles: l'Algérie dans la tradition méditerranéenne (Paris: Robert Laffont, 1962); and later without change, rather confusingly, under the different title of Tradition et civilisation Berbères: les portes de l'année (Monaco: Éditions du Rocher, 1985).

89 SHAT $1 \mathrm{H} 2563 / 2 *$, note on Servier, État-major, Bureau Psychologique, 28 June 1957; CAOM 13CAB7, Jean Servier to Directeur Général de la Fonction Publique et des Affaires Politiques (GG), 12 August 1956.

90 This operation, and Servier's role in it as adviser, has been studied by the leading ethnologist of Kabylia, Camille Lacoste-Dujardin in Opération 'Oiseau Bleu': des Kabyles, des ethnologues et la guerre d'Algérie (Paris: La Découverte, 1997), see especially 47-9, 254-72; also by General Maurice Faivre, 'L'Affaire K, comme Kabyle (1956)', Revue d'histoire, guerre mondiale et conflits contemporains, 191 (1998), 37-67; see also Yves Courrière, La Guerre d'Algérie, Vol. 2, Le Temps des léopards (Paris: Fayard, 1969), 244-63; for Servier's own rather opaque account see Adieu Djebels (Paris: Éditions France Empire, 1958), 13-118, a book that was banned by the government.

91 Camille Lacoste-Dujardin has replied to an attack by General Faivre on her critique of Servier in 'Une auto-intoxication de services secrets. Histoire et ethnologie dans la guerre d'Algérie', in Pierre Brocheux et al. (eds), La Guerre d'Algérie au miroir des décolonisations françaises (Paris: SFHOM, 2000), 573-91. 
92 Servier's accounts of his adventurous exploits need to be treated with some caution: a document in SHAT 1H2536/2* of the Bureau Psychologique, 28 June 1957, probably by Goussault, notes that the essentials of Operation Pilot had already been presented to the Paris École Supérieure de Guerre as early as May 1956.

93 Servier, Adieu Djebels, 144-56; SHAT 1H2536/2*, note of Salan 29 January 1957. The term 'reconquête' bears an interesting resemblance to the Spanish 'reconquista', the centuries-long process of Christian warfare that eventually led to the expulsion of the Muslim population.

94 SHAT 1H2536/2*, Bureau Psychologique, Algiers 16 January 1957, 'Fiche au sujet de l'opération de Monsieur Servier'.

95 SHAT $1 \mathrm{H} 2536 / 2 *$, Colonel Goussault to Général Dulac, 17 January 1957.

96 Courrière, La Guerre d'Algérie, Vol. 2, 23. Lucien Paye (1907-72) was another of the academic specialists on the Maghreb that advised Soustelle: he was later Minister of Education (February 1961-April 1962) and ambassador to Senegal and China (1964-69).

97 Part of Servier's doctoral thesis of 1955 was on, 'Chants rituals et chants de circonstances des femmes de l'Aurès'.

98 CAOM 13CAB7. Servier to Paye, 12 August 1956: the second report was on the marabouts and the Koranic schools (zaouias).

99 CAOM 13CAB7, note for Monsieur Villeneuve, 20 August 1956 [from Paye?], instructing him to plan with Le Tourneau, the Rector, a project for 'a school of domestic science for young Kabyle girls'.

100 SHAT $1 \mathrm{H} 2536 / 1^{*}$, undated; no author is given, but the document, on internal evidence, can be attributed to Servier.

101 SHAT 1H2536/1*, L'Algérie française pivot de l'Eurafrique, undated.

102 Servier, Dans l'Aurès, recounts how during fieldwork during 1949-54 he found much evidence of Ulema penetration into the Berber tribes and its violent opposition to traditional festivals, singing, dancing, cafés, alcohol, coffee, tobacco and cinemas: see 8-9, 149-54, 248. Fanny Colonna, Les Versets de l'invincibilité. Permanence et changements religieux dans l'Algérie contemporaine (Paris: FNSP, 1995), confirms this early Ulema penetration into rural Algeria.

103 CAOM 13CAB7, Servier, 'Note sur les Écoles Koraniques de Kabylie Maritime', 12 August 1956.

104 SHAT 1H2536/1*, L'Algérie française pivot de l'Eurafrique. This undated document, probably by Servier, was later reused verbatim to form the core of a standard guide for army officers engaged in propaganda on emancipation: see SHAT 1H2582, Fifth Bureau, État-Major, 21 November 1958.

105 SHAT 1H2556/1, Lacoste circular, 'Action civique par les SAS', 4 February 1958 , outlines this two stage model of pacification.

106 SHAT $1 \mathrm{H} 2536 / 2 *$. A detailed eye-witness account of the operations was provided by Jean Piverd in five articles in L'Aurore, 26 June to 1 July 
1957, the first titled 'J'ai vu les hommes de bonne volonté travailler à l'édification de l'Algérie Nouvelle'. General Dulac was furious that Servier had broken orders by escorting Piverd, who revealed the location and nature of the operation: see SHAT $1 \mathrm{H} 2536 / 2 *$, note of General Dulac, Chef État-Major, Algiers 28 June 1957.

107 There were initially ten of these allocated to Pilot, all of them ex-prisoners of the Viet Minh who had experienced 'brain washing' techniques: SHAT 1H2409: Salan report August 1957.

108 On the CHPT units see chapter 4.

109 During Operation Pilot the term Assistance médicale sociale rurale itinérante was used, which then became the official ASSRA (Adjointes sanitaires et sociales rurales auxiliaries) in October 1957. The term Équipes medico-sociales itinérantes (EMSI), which referred to each team of two or three ASSRA, does not seem to have come into use until late 1957, but I have used it here to refer to the earlier experimental organisation. A fuller account of the EMSI is given in chapter 7 .

110 SHAT $1 \mathrm{H} 2536 / 1 *$.

111 L'Aurore, 27 June, 1 July 1957.

112 Piverd's fifth report in L'Aurore, 1 July 1957, centred on the festivities of opening a new school, titled, 'Une école détruite, c'était la disparation de la France ... Alors, j'en ai construit une autre'.

113 SHAT H2536/2*, Salan to commander Division Militaire d'Alger [n.d], provides orders for the careful selection and training of nineteen officers, 'to provide supervision for the Centre for Training of Political Commissioners'.

114 Villatoux and Villatoux, La République, 464-6. On Arzew see Frédéric Guelton, 'The French Army "Centre for Training and Preparation in Counter-Guerrilla Warfare" (CIPCG) at Arzew', in Martin S. Alexander and J. F. V. Keiger (eds), France and the Algerian War, 1954-62: Strategy, Operations and Diplomacy (London: Frank Kass, 2002), 35-53.

115 SHAT $1 \mathrm{H} 2536 / 2^{*}$, a report (probably by Goussault), Algiers Bureau Psychologique to Salan, 17 July 1957, notes three of five douars north of the Chélif valley were now entirely 'pacified' and, 'Local councils have been elected by the population and our former trainees from Arzew are in place and are undertaking excellent work both in relation to politics and intelligence gathering'.

116 SHAT 1H2536/1*, Bureau Psychologique, 28 June 1957; Courrière, La Guerre d'Algérie, Vol. 2, 27.

117 SHAT $1 \mathrm{H} 2536 / 1^{*}$, a note (probably by Servier), sees the ASSRA as typically coming from an educated, urban background, 'usually belonging to wealthy families', who could initiate peasant women to 'modern life': the FLN moudjahidates nurses came from a similar background (see chapter 9).

118 Servier, Adieu Djebels, 188-94; Courrière, La Guerre d'Algérie, Vol. 2, 26; confirmed by SHAT 1H246/1, Fiche 18 May 1957, on Louisa Fadli. 
119 L'Aurore, 29-30 June, 1957, titled, 'With Denise, the Parisian welfare assistant, and Touria, the Algerian, who was, against her wishes, a nurse with the bandit gangs'.

120 Servier, Adieu Djebels, 204-5. This school does not seem to have ever started operation, probably because of Servier's later removal by the military command.

121 ECPAD - ALG 57/392 contains some of the earliest photographs of the EMSI taken by an army photo-journalist, 16 August 1957, who visited the team headed by Mme Guille that operated in the Bou Maad area.

122 Christiane Fournier, Les EMSI: des filles comme ça! (Paris: Arthème Fayard, 1959).

123 Servier, Adieu Djebels, 196; Courrière, La Guerre d'Algérie, Vol. 3, 32.

124 SHAT 1H2536/2*, Goussault report, 17 July 1957.

125 Villatoux and Villatoux, La République, 475-8, provides a detailed reconstruction of the extension of Pilot to Casseigne [now Sidi Ali], north-east of Mostaganem.

126 SHAT 1H2536/2*, Salan to General CAA, 30 June 1957.

127 SHAT $1 \mathrm{H} 2536 / 1$, Note sur l'emploi des musulmans dans l'armée, 3 September 1957 [n.d. or author, but almost certainly by Servier]; Servier told Courrière, La Guerre, Vol. 3, 27, that Fifth Bureau officers allowed 'their nostalgic memories of Indochina to influence the Algerian situation'.

128 SHAT 1H2536/2*, Goussault to Salan, 17 July 1957, noted in the Ouarsensis (where 'Pilot 2' was originally planned): 'The artillery and aviation are deployed frequently without much concern for the damage inflicted on the population'.

129 SHAT $1 \mathrm{H} 2536 / 1^{*}$, in a note of 28 June 1957 Goussault made a detailed critique of Servier's failings.

130 SHAT $1 \mathrm{H} 2536 / 2 *$, Bureau psychologique, fiche on Operation NK-3, 3 June 1957.

131 SHAT 1H2536/2*, note of Lt-Colonel Besson, Fifth Bureau, CAA, 24 May 1957.

132 SHAT 1H2569, report by Lt.-Colonel Beaudu, Chargé Action Psychologique, Secteur Saint-Charles, 4 December 1957.

133 Courrière, La Guerre d'Algérie, Vol. 3, 26, initially five army nurses, Personnel féminine de l'armée de terre (PFAT), released by General Allard.

134 SHAT 1H4395/7, Lacoste, order of 25 October 1957. A detailed assessment of the EMSI is provided in chapter 7.

135 SHAT 1H2536/2*, General de Brébisson note to Algiers Command, 24 February 1957: 'The key idea of Servier must be the liberation of the masses from poverty and ignorance, and the emancipation of women, aims that the FLN, by its very nature, is unable to pursue'.

136 Amrane, Les Femmes algériennes, 220-3; Kessel and Pirelli (eds), Le Peuple algérien, 130-4. Of the total number of 10,949 women militants 
officially registered after the war with the Ministry of Veterans (Ministère des Moudjahidine), 0.29 per cent joined the FLN in 1954, 7.9 per cent in 1955, and 23.5 per cent in 1956, see Djamila Amrane, 'Approche statistique de la participation de la femme algérienne à la guerre de liberation nationale (1954-1962)', in Majallat et-Tarikh, No. 10, 1981, Algiers, 90, quoted in Diane Sambron, Femmes musulmanes. Guerre d'Algérie 1954-1962 (Paris: Éditions Autrement, 2007), 30.

137 Courrière, La Guerre d'Algérie, Vol. 1, 98-9.

138 SHAT 1H2582, FLN Circular No. 9, 2 May 1957.

139 There is an extensive literature on the 'Battle of Algiers', but see in particular: Yacef Saadi, La Bataille d'Alger, 2 Vols (Paris: Publisud, 2002 edn); General Jacques Massu, La Vraie bataille d'Alger (Paris: Plon, 1971); Pierre Pallissier, La Bataille d'Alger (Paris: Perrin, 1995).

140 For a detailed account of a typical itinerary of engagement see Commandant Azzedine's account of his niece Zehor Zerari in, On nous appelait fellaghas, reprinted in Jean-Claude Carrière and Commandant Azzedine, C'était la guerre. Algérie 1954-1962 (Paris: Plon, 1992), 338-58.

141 Ibid., 49.

142 Ibid., 53-4; thirty-six assistants signed the letter.

143 House and MacMaster, Paris 1961, 144-6.

144 On the campaign against the Centres sociaux, in which Colonel Gardes, head of the Fifth Bureau, played a key role, see LeSueur, Uncivil War, 62-86; Forget, 'Le Service'.

145 SHAT 1H2461/1, Fifth Bureau, Action Psychologique sur l'organisation féminine de la Zone Autonome d'Alger (ZAA), 11 October 1957; 1H2582, Second Bureau État-Major, 10e Région, 14 October 1957, Organisation féminine de la ZAA.

146 CAOM 81F1218, Directeur Générale des Affaires Politiques, 19 December 1957.

147 CAOM 14CAB162, Massu to IGAME, Algiers, 26 April 1958.

148 CAOM 14CAB162, Allard to Salan, 6 May 1958. 